\title{
Judicial Deference to Administrative Interpretation of Statutes from a Comparative Perspective
}

\author{
Vincent Martenet
}

\begin{abstract}
This Article examines, from a comparative perspective, how judicial deference to administrative interpretation of statutes takes place and whether it is constitutionally admissible. Since constitutions and statutes rarely deal expressly with this issue, courts may have to determine whether or not such deference is permitted, and, if so, whether generally or in certain cases only. The constitutional, legal, and judicial context prevailing in each country is particularly important in this regard. Nevertheless, it may provide courts with little, if any, guidance on the specific issue of deference to administrative statutory interpretation. In this respect, a nuanced approach along all or part of the following lines may be appropriate: When (i) in light of the applicable methods and canons of construction, a statute allows a margin of interpretation, (ii) the administrative interpretation of the statute remains within this margin, and (iii) the applicable international, constitutional, statutory or other constraints permit or, at least, do not exclude judicial deference either generally or in the case at hand, then courts may or, depending on the country, must defer to the administrative interpretation of the statute, especially when or, depending on the country, provided that (iv) this interpretation requires
\end{abstract}

\footnotetext{
Full Professor of Swiss and comparative constitutional law as well as competition law at the University of Lausanne, Switzerland; Director of the Law School of the University of Lausanne; Deputy Justice, Swiss Federal Tribunal, the Supreme Court of Switzerland; former President of the Swiss Competition Commission. I am indebted to Alexandre Arruda, Jeffrey Barnes, Luis José Béjar Rivera, Violeta Canaves, Geneviève Cartier, Cora Chan, Margit Cohn, Diogo R. Coutinho, Paul Craig, Paul Daly, Mathieu Devinat, Cora Hoexter, Leo Jedwab, Norikazu Kawagishi, Roopashi Khatri, Dong Won Kim, Zdenek Kühn, Luciano D. Laise, Shaheeza Lalani, Saskia Lavrijssen, Olli Mäenpää, Bent Ole Gram Mortensen, Mariana Mota Prado, Vera Parisio, Thomas Perroud, Étienne Poltier, David Renders, Dominik Rennert, Heike Schweitzer, Stefan Storr, Sophie Weerts, Henrik Wenander and Hanna Wilberg for their helpful comments. I thank Clémence Demay, Julia Kamhi and Stéphanie Tumini from the University of Lausanne, as well as Sadri Saieb from the Swiss Institute of Comparative Law for their excellent research assistance. Finally, I address many thanks to the editors of the Vanderbilt Journal of Transnational Law.
} 
non-legal expertise, $(v)$ the administrative body enjoys an asymmetry of such expertise as compared to courts, and (vi) the legislature was or should have been aware of both this necessity and this asymmetry. The level of courts' expertise in the relevant subject-matter should, in principle, be determined after taking account of the measures available to judges, including the appointment of experts. The proposed test may notably be followed where the disputed interpretation requires a prediction, appraisal or assessment.

\section{TABle of Contents}

I. INTRODUCTION ........................................................ 85

II. COUNTRIES CONSIDERED AND PURPose OF THE COMPARISON

III. Preconditions For Deference in Cases InVolving the INTERPRETATION OF STATUTES..................................... 91

A. Interpretation of Statutes and Margin of Interpretation ...................................... 92

B. International, Constitutional, Statutory, and Other Constraints................................. 96

C. $\quad$ The Legislature's Intent or Assent ........ $\quad 97$

IV. THE CASE FOR JUDICIAL DEFERENCE ........................... 102

A. Administrative Legitimacy and the Separation of Powers ............................................... 102

1. Expertise........................................ 102

2. Political Accountability ................... 105

3. Independence................................... 107

4. Political Discretion .......................... 108

B. Optimal Allocation of Resources........... 110

C. Judicial Honesty, Transparency, and Humility

D. Other Considerations

V. The CASE AGAinst Judicial DEFEREnCE .................... 115

A. Separation of Powers and Checks and Balances................................................ 115

B. $\quad$ Rule of Law and "État de droit"........... 116

C. $\quad$ Constitutional Role of the Judiciary .... 119

D. Procedural Safeguards......................... 121

E. Independence ....................................... 124

F. Risk of Wrong Incentives and Other

Considerations...................................... 125

VI. THE ROOM FOR DEFERENCE ..................................... 126

A. International, Constitutional, Statutory, and Other Limits ......................................... 126

B. Asymmetry of Non-Legal Expertise ...... 129

C. Conceivable Criteria for Deference ....... 135 
1. Explicitly or Actively Enabling Judicial

Deference

2. Implicitly or Passively Enabling Judicial

Deference

D. Specific Comments Regarding Canada and the

United States ........................................... 143

VII. CONCLUSION

144

\section{INTRODUCTION}

Different decision-making bodies make administrative decisions. Agencies with some-substantial or limited-independence from government exist, for instance, in several democratic countries. Those agencies' officials and staff are usually specialists with profound knowledge of the field for which they are responsible. One of their tasks consists of interpreting and applying the statutes that they administer. Agencies belong to the executive branch of the government and form functionally separate units within this branch. They may be numerous in some countries, like France, ${ }^{1}$ and few in others, such as in Germany. $^{2}$

This Article deals with administrative decisions, that is, decisions taken by administrative bodies or decision-makers, in particular by agencies. Several ideas in this Article may actually apply to the executive branch in its entirety, including to the head of state or government. Nonetheless, courts and scholars have specifically dealt with the interpretation of statutes by agencies or other administrative bodies and subsequent review of this interpretation by courts. The bulk of judicial decisions and scholarly publications are of great interest, particularly from a comparative perspective. Administrative decisions, with some exceptions, can be appealed to courts. Most judges hear cases on a wide range of issues and, accordingly, may be considered as generalists. However, legal interpretation is one of their core

1. $\quad$ See infra Part IV.A.3.

2. See, e.g., Georg Hermes, Abhängige und unabhängige Verwaltungsbehörden: Ein Überblick über die Bundesverwaltung [Dependent and Independent Administrative Authorities: An Overview of the Federal Administration], in UNABHÄNGIGE REGULIERUNGSBEHÖRDEN [INDEPENDENT REGULATION AUTHORITIES] 53, 85-86 (Johannes Masing \& Gérard Marcou eds., 2010). The German Federal Constitutional Court considers that "the establishment of independent agencies does not . . meet with any fundamental objections, but remains precarious from the democratic imperative's perspective." Bundesverfassungsgericht [BVERFG] [Federal Constitutional Court] July 30, 2019, 151 ENTSCHEIDUNGEN DES BUNDESVERFASSUNGSGERICHTS [BVERFGE] 202, 295 (Ger.). 
competencies-if not their main competency. ${ }^{3}$ While reviewing a case, judges may have to assess the administrative interpretation of a statute. Broadly speaking, the judiciary examines a decision of the executive based on an act emanating from the legislature. The separation of powers principle and the concept of checks and balances form the backdrop of this subject.

Judicial review of administrative decisions often raises the question of deference from courts. There can be many instances of judicial deference in a single country, ${ }^{4}$ which overlap to a certain or greater extent. ${ }^{5}$ The distinction between these various types of deference is the subject of scholarly critique in certain jurisdictions. Some scholars plead for a clearer, more unified understanding of the notions of administrative discretion and judicial deference. ${ }^{6}$ This Article's aim is not to elaborate a typology in this regard. Suffice it to say, even after simplifying the approach for considering administrative discretion and judicial deference, these scholars usually acknowledge that the latter would still relate to statutory interpretation, ${ }^{7}$ among other elements.

3. For views from federal appellate judges themselves in the United States, see Abbe R. Gluck \& Richard A. Posner, Statutory Interpretation on the Bench: A Survey of Forty-Two Judges on the Federal Courts of Appeals, 131 HARV. L. REV. 1298, 1348-50 (2018) ("[M]ost of the judges we interviewed do not favor the Chevron rule [judicial deference to agency statutory interpretation when certain conditions are met]. Here is where we see a 'D.C. Circuit effect' in our study. All but one of the D.C. Circuit judges we interviewed-who were of different generations and political parties-were admirers of Chevron deference, whereas most other judges from the other courts of appeals were decidedly anti-Chevron.”).

4. Regarding Germany, see, for example, Jan S. Oster, The Scope of Judicial Review in the German and U.S. Administrative Legal System, 9 GER. L.J. 1267, 1269-75 (2008); Wolfgang Hoffmann-Riem, Eigenständigkeit der Verwaltung [Autonomy of the Administration], in 1 GRUNDLAGEN DES VERWALTUNGSRECHTS [FOUNDATIONS OF ADMinistrative LAW] 677, 727-28 (Wolfgang Hoffmann-Riem, Eberhard SchmidtAßmann \& Andreas Vossßkuhle eds., 2nd ed. 2012). Regarding the United States, see, for example, John C. Reitz, Deference to the Administration in Judicial Review, 66 AM. J. COMP. L. 269, 272 (2018).

5. Regarding Germany, see, for example, JAN OSTER, NoRMATIVE ERMÄCHTIGUNGEN IM REGULIERUNGSRECHT [NORMATIVE AUTHORIZATIONS IN REGULATION] 60-68 (2010).

6. Regarding Germany, see, for example, Matthias Jestaedt, Maßstäbe des Verwaltungshandels [Standards in Administrative Action], in ALLGEMEINES VERWALTUNGSRECHT [GENERAL ADMINISTRATIVE LAW] 325, 334-41 (Dirk Ehlers \& Hermann Pünder eds., 15th ed. 2016); Guy Beaucamp, Ermessens und Beurteilungsfehler im Vergleich [Errors of Assessment and Judgment from a Comparative Perspective], 2012 JURISTISCHE ARBEITSBLÄTTER [LEGAL WORKSHEETS] 193, 194. For an assessment of this view, see OsTER, supra note 5, at 60-68. Regarding Switzerland, see, for example, BENJAMIN SCHINDLER, VERWALTUNGSERMESSEN [ADMINISTRATIVE DISCRETION] 328-29, 339, 383, 407-08 (2010); THIERRY TANQUEREL, MANUEL DE DROIT ADMINISTRATIF [ADMINISTRATIVE LAW HANDBOOK] 177-79 (2d ed. 2018).

7. Regarding Germany, see, for example, Jestaedt, supra note 6, at 335-37; Beaucamp, supra note 6, at 195. Regarding Switzerland, see, for example, SCHINDLER, 
This Article is devoted to judicial deference on questions of legal interpretation, which must be answered by applying relevant principles to the interpretation of the law. A distinction has been made between law-based deference-founded on the statutory delegation, to administrative bodies, of powers to promulgate rules and regulations with the force of law and to adjudicate disputes in specific areas with the force of law-and fact-based deference-grounded in the courts' appreciation of the expertise and experience of the administrative body. ${ }^{8}$ In many cases, however, both reasons for judicial deference tend to blend and may actually operate together. ${ }^{9}$ This Article actually combines them without blurring the line between them. It is predicated on the idea that a legislature may explicitly or implicitly enable or even require courts to exercise deference with respect to the administrative interpretation of statutes, notably because of the relevant administrative bodies' expertise and experience. Therefore, this Article links a normative dimension of deference-the allocation of interpretive authority - to a factual one - the asymmetry of non-legal expertise between agencies or other administrative bodies and courts.

Specifically, this Article deals with judicial deference in cases involving the interpretation of statutes. The issue is quite straightforward when such a limit to the judges' power is expressly foreseen by the constitution or the applicable laws, bearing in mind that the constitutionality of a law may still be challenged. However, such deference, if and when it arises, is usually not based on a specific constitutional provision or statute. Rather, it results from broader considerations related to inter-branch relations.

This Article focuses on the relationship between administrative bodies and courts when the interpretation of an ambiguous or unclear statute is disputed as opposed to when administrative policy determinations are challenged, except when these raise issues relating to the interpretation of statutes. ${ }^{10}$ Judicial deference to administrative interpretation of statutes is possible not only in Canada and in the United States, but also in other countries. ${ }^{11}$ Questions relating to the

supra note 6, at 407-09; TANQUEREL, supra note 6, at 178-79; Le contrôle de l'opportunité [Control of Opportunity], in LE CONTENTIEUX ADMINISTRATIF [ADMINISTRATIVE DisPUTE] 209, 219-23 (François Bellanger \& Thierry Tanquerel eds., 2013).

8. Regarding the United States, see Reitz, supra note 4, at 272.

9. Regarding Germany, see, for example, Martin Eifert, Letztentscheidungsbefugnisse der Verwaltung: Ermessen, Beurteilungsspielräume sowie Planungsentscheidungen und ihre gerichtliche Kontrolle [Ultimate Decision-Making Powers of the Administration: Discretion, Latitudes of Judgement, Planning Decisions, and their Judicial Control], 2008 ZEITSCHRIFT FÜR DAS JURISTISCHE STUDIUM [J. FOR LEGAL STUD.] 336, 339-40.

10. On this distinction, see infra Parts II, III.A.

11. Regarding Germany and Switzerland, for instance, see infra Parts III.A, VI.C.2. 
relationship between administrative bodies and courts in statutory interpretation cases arise in several democratic countries, regardless of their legal traditions. ${ }^{12}$ They invite us to reflect from a comparative perspective, without ignoring the constitutional, legal, and judicial context prevailing in each country, and being fully aware that generalizations regarding judicial deference should be, if not completely avoided, at least very carefully crafted. A nuanced approach is actually inevitable.

This Article, which includes seven parts, presents a few thoughts on judicial deference to administrative interpretation of statutes, based on a comparative review. Following the introduction (Part I), Part II justifies the choice of the countries considered and explains the purpose of this comparative study. Part III sets out relevant preconditions for deference in cases involving the interpretation of statutes. Parts IV and V respectively make the case for and against judicial deference to administrative interpretation of statutes. Based on this, Part VI evaluates possible limits and criteria for such deference. In the Article's conclusion (Part VII), deference is described as oil in the complex machinery of checks and balances.

\section{COUnTRIEs CONSIDERED AND PURPose OF THE COMPARISON}

Twenty-seven countries and a special administrative region have been considered in this Article. ${ }^{13}$ In addition, the European Union and the Council of Europe have also been included, as the case law, respectively, of the Court of Justice of the European Union and the European Court of Human Rights is relevant in this field. This comparative study is the broadest one among academic articles ${ }^{14}$ on the specific issue of judicial deference to administrative interpretation of statutes. ${ }^{15}$ Although books have been published in this field, some

12. See infra Part III.

13. Argentina, Australia, Austria, Belgium, Brazil, Canada, the Czech Republic, Denmark, Finland, France, Germany, Hong Kong (Special Administrative Region of the People's Republic of China), India, Israel, Italy, Japan, Mexico, the Netherlands, New Zealand, Poland, Singapore, South Africa, South Korea (the Republic of Korea), Spain, Sweden, Switzerland, Taiwan (Republic of China), the United Kingdom, and the United States. China is also briefly mentioned in this Article.

14. See generally Paul Craig, Judicial Review of Questions of Law: A Comparative Perspective, in Comparative AdMINISTRATIVe LaW 389 (Susan Rose-Ackerman, Peter L. Lindseth, \& Blake Emerson eds., 2d ed. 2017) (examining aspects of legal systems of Canada, the European Union, the United Kingdom, and the United States); Paul Daly, Deference on Questions of Law, 74 MOD. L. REV. 694 (2011) [hereinafter Daly, Deference on Questions of Law] (examining aspects of the legal systems of Canada, the United Kingdom, and the United States); Oster, supra note 4 (examining aspects of the legal systems of Germany and the United States).

15. Unclear issues have been verified by specialists of the relevant countries, who are acknowledged in the first footnote. 
are limited in geographical scope, while others have a broader focus and do not look specifically at legal interpretation. ${ }^{16}$

While the choice of countries is also based on the availability of data, it should primarily allow for coverage of most of the countries where adherence to the rule of law may be qualified as strong. ${ }^{17}$ Since the topic of this Article relates to legal interpretation and to the relationship among the legislative, executive, and judiciary branches, it is rooted in the rule of law and judicial independence. When the rule of law and judicial independence are not sufficiently guaranteed, it is difficult to conduct a principled analysis of judicial deference to administrative interpretation of statutes. The choice of countries also allows for diversity in terms of legal systems and geography in order to avoid either a European- or a North American-centric view.

This Article firstly aims to identify preconditions for deference in cases involving interpretation of statutes. The comparative perspective is useful, as it helps to assess whether the issue of judicial deference to administrative interpretation of statutes is closely linked to a particular system. As this Article will demonstrate, the relevant preconditions are quite general and may be met in many countries,

16. See generally DEFERENCE TO THE ADMINISTRATION IN JUDICIAL REviEW: Comparative PERsPeCtives (Guobin Zhu ed., 2019) (most of the chapters in this book do not, however, focus on judicial deference to administrative interpretation of statutes); Judicial REVIEW of AdMinistrative Discretion in the AdMinistrative State (Jurgen de Poorter, Ernst Hirsch Ballin, \& Saskia Lavrijssen eds., 2019) (examining aspects of legal systems of the European Union, the Netherlands and the United Kingdom); MATtheW LeWANs, AdMinistrative LAW AND JUdiCial DEFERENCE (2018) (examining aspects of the legal systems of Canada, Israel, New Zealand, South Africa, the United Kingdom, and the United States); EDUARDO JORDÃO, LE JUGE ET L'ADMINISTRATION: ENTRE LE CONTRÔLE ET LA DÉFÉRENCE [THE JUDGE AND THE ADMINISTRATION: BETWEEN CONTROL AND DEFERENCE] (2016) (examining aspects of the legal systems of Canada, France, Italy and the United States); PAUL DALY, A THEORY OF DEFERENCE IN ADMINISTRATIVE LAW: BASIS, APPLICATION AND SCOPE (2012) (examining aspects of the legal systems of Canada, New Zealand, the United Kingdom and the United States); Oster, supra note 4 (examining aspects of the legal systems of Germany and the United States).

17. The Article covers 18 of the first 20 countries listed in the ranking "Rule of Law Around the World" published by the World Justice Project. For the 2020 Index, see World Justice Project, Rule OF LAW Index 20205 (2020), https://worldjusticeproject.org/sites/default/files/documents/WJP-ROLI-2020-

Online_0.pdf [https://perma.cc/2KB8-5NJ7] (archived Sept. 26, 2020) (presenting itself as "the world's most comprehensive dataset of its kind and the only to rely principally on primary data"). Norway and Estonia were not purposely left out in this Article, but reliable data regarding the topic of this Article could not be found for them. European countries are already well represented in our analysis. Approximately two thirds of the countries belonging to the Organisation for Economic Co-operation and Development (OECD) and all of the major jurisdictions among them are covered in this Article. The OECD is deemed to "form a community of nations committed to the values of democracy based on rule of law and human rights". See ORGANISATION FOR ECONOMIC COOPERATION AND DEVELOPMENT (OECD), OECD 50TH ANNIVERSARY VISION STATEMENT 2 (2011), https://www.oecd.org/mcm/48064973.pdf [https://perma.cc/HWQ9-JXD3] (archived Sept. 26, 2020). 
which means that this question can arise —and does actually arise-in different legal systems.

Since judicial deference to administrative interpretation of statutes depends on rather loose preconditions, this Article secondly analyzes the arguments made in favor of or against such deference in several countries. Here also, the comparative perspective is interesting and even fascinating as similar arguments exist in most, if not all, of the countries examined, but are weighed differently. 18 These similarities may lead to a nuanced approach with respect to judicial deference to administrative interpretation of statutes.

This Article tries to use the collected data to define, from a comparative perspective, limits and criteria for judicial deference to administrative interpretation of statutes. Depending on the country, the room for deference may be broader, narrower, or nonexistent. Common ground between different countries may be brought to light through a comparative study and may indicate where the case for judicial deference to administrative statutory interpretation is strongest. Judges in some countries may find comparative support for the doctrine they have developed, but, at the same time, may take into consideration arguments to limit the doctrine. Judges in other countries may see reasons to reconsider their position against any judicial deference in statutory interpretation cases.

Given the significant cross-national variation in administrative law systems, this Article is framed with an awareness of national differences but is not hindered by this. Many important factors that might come into play have been considered in order to come up with a way of thinking about deference which could intelligibly apply to different countries. Nevertheless, various features in administrative law systems may significantly affect debates about deference. The difference between review in specialized administrative courts or tribunals versus general jurisdiction courts may influence approaches to deference. ${ }^{19}$ The possibilities for a court to appoint experts may also play a role in this respect. This Article takes these issues into account, as it puts at its center the asymmetry of non-legal expertise between administrative bodies and courts. ${ }^{20}$ Depending on many factors, this asymmetry may be minimal or important. The processes by which

18. For a comparative perspective, see, for example, Guobin Zhu, Deference to the Administration in Judicial Review: Comparative Perspectives, in DEFERENCE TO THE ADMINISTRATION IN JUDICIAL REVIEW, supra note 16, at 1, 10-11.

19. But see Despoina Mantzari, Judicial Scrutiny of Regulatory Decisions at the UK's Specialist Competition Appeal Tribunal, in JUdiCial REVIEW OF ADMINISTRATIVE Discretion IN THE ADMINISTRATIVE STATE, supra note 16, 63, 80 ("Even specialist tribunals are limited in their ability to decide on regulatory remedies, which involve the representation of diverse interests, the balancing of a variety of goals, and prospective analysis.").

20. See infra Parts IV.A.1, VI.B. 
statutes are drafted and the way-precise or vague, for instance-in which they are written, may also affect the salience of the issue. The breadth of delegation to agencies or other administrative bodies of powers to adjudicate disputes in specific areas with the force of law may considerably vary from one country to another.

Furthermore, this Article insists on the margin of interpretation that a statute must allow in order for the issue of deference to potentially appear. ${ }^{21}$ It also emphasizes the role of the legislature, ${ }^{22}$ which may vary from one country to another or from one piece of legislation to another in the same country. In other words, this Article is based on a nuanced approach and gives attention to how systemic or structural differences between countries or within a given country might bear on deference issues. Finally, without any claim to completeness, the way proceedings and deliberations are conducted by agencies or other administrative bodies-court-like or more government-like, for instance-as well as the parties' degree of involvement and procedural rights in those proceedings-with disparities or similarities between countries ${ }^{23}$-may impact the debate on judicial deference. The importance of procedural safeguards, with respect to the issues covered, is given prominence in this Article. ${ }^{24}$

\section{Preconditions for Deference in CASEs Involving the INTERPRETATION OF STATUTES}

Judicial deference to administrative interpretation of statutes may arise where three main preconditions are met. Firstly, the statute in question allows a margin of interpretation with respect to the specific issue raised (subpart A). Secondly, the court's deference must fit within international, constitutional, as well as statutory or other constraints (subpart B) and, thirdly, the court's deference must somehow be willed or accepted by the legislature (subpart C).

21. See infra Parts III.A, VI.C.2.

22. See infra Parts III.C, VI.C.

23. Regarding the United States and Germany, see Hermann Pünder, German Administrative Procedure in a Comparative Perspective: Observations on the Path to a Transnational Ius Commune Proceduralis in Administrative Law, 11 INT'L J. CONST. L. 940, 950 (2013) (“[L]ooking at 'formal adjudications,' . . . [t] he procedural requirements in the two jurisdictions are quite alike. The conflict between the demand for democratic decision-making under the rule of law and administrative efficiency is resolved in a similar way in both countries.").

24. See infra Parts III.B, V.D, VI.A. 


\section{A. Interpretation of Statutes and Margin of Interpretation}

In the context of this Article, the interpretation of statutes refers, broadly speaking, to the process of determining the meaning of statutory provisions. An agency or another administrative body that administers a statute, and the court that reviews the decisions based on the statute, must carry out this process. This issue becomes especially interesting when the relevant statutory provision is ambiguous or unclear. This Article does not deal primarily with judicial control over administrative decisions when a statute, in itself clear, allows an administrative body to choose among several possibilities and grants it a margin of discretion or appreciation in this regard. ${ }^{25} \mathrm{In}$ such a case, questions relating to the interpretation of the statute may arise, but they are typically not at the core of the litigation in judicial proceedings, which will focus in many countries, for instance, on the principle of proportionality. ${ }^{26}$ This Article covers this issue when the provision granting administrative discretion, for example regarding the possibility to choose between several measures, is itself ambiguous. In such a case, the statute's interpretation becomes crucial when the administrative body and then the court determine the scope of discretion that the first enjoys and that the second must respect.

The debate on judicial deference to administrative interpretation of statutes essentially arises where an unclear or ambiguous statute must initially be interpreted by an administrative body and then by a court. In the United States, the statute must be "silent or ambiguous with respect to the specific issue," according to the landmark Chevron decision of the Supreme Court. ${ }^{27}$ In Canada, the Supreme Court follows a similar approach, at least in some cases:

because legislatures do not always speak clearly and because the tools of statutory interpretation do not always guarantee a single clear answer, legislative provisions will on occasion be susceptible to multiple reasonable

interpretations. ... [T] he resolution of unclear language in an administrative

25. On the distinction between margin of appreciation and margin of discretion, see Rob Widdershoven, The European Court of Justice and the Standard of Judicial Review, in JUDICIAL REVIEW OF ADMINISTRATIVE DisCRETION IN THE ADMINISTRATIVE STATE, supra note 16, at 39, 53 (noting that, "in the case law of the [European Court of Justice,] such distinction is generally not made and both terms are used interchangeably").

26. On proportionality as a "master concept of public law," even though there is no explicit "proportionality review" in American administrative law, see Jud Mathews, Proportionality Review in Administrative Law, in COMPARATIVE ADMINISTRATIVE LAW, supra note 14, at 405-06. Regarding the United States specifically, see generally Jud Mathews, Agency Discretion, Judicial Review and 'Proportionality' in US Administrative Law, in The Judge and the Proportionate Use of Discretion: A Comparative ADMINISTRATIVE LAW STUdY 160 (Sofia Ranchordás \& Boudewijn de Waard eds., 2015).

27. Chevron, U.S.A., Inc. v. Nat. Res. Def. Council, Inc., 467 U.S. 837, 842-43 (1984). 
decision maker's home statute is usually best left to the decision maker. That is so because the choice between multiple reasonable interpretations will often involve policy considerations that we presume the legislature desired the administrative decision maker - not the courts-to make. Indeed, the exercise of that interpretative discretion is part of an administrative decision maker's "expertise." . . It will not always be the case that a particular provision permits multiple reasonable interpretations. Where the ordinary tools of statutory interpretation lead to a single reasonable interpretation and the administrative decision maker adopts a different interpretation, its interpretation will necessarily be unreasonable - no degree of deference can justify its acceptance.... In those cases, the "range of reasonable outcomes" . . . will necessarily be limited to a single reasonable interpretation-and the administrative decision maker must adopt it. ${ }^{28}$

In Germany or Switzerland, for instance, the statute must contain an "indefinite legal term," 29 though this is only a precondition for eventual judicial deference. ${ }^{30}$ In Austria, the federal Constitution provides that

[e]xcept in administrative penal proceedings and in legal matters pertaining to the competence of the Administrative Court of the Federation for Finance, illegality does not exist to the extent the law permits the administrative authority to apply discretion and the authority has done so in the sense of the law. ${ }^{31}$

It is now considered that this provision does not prevent the adoption of federal statutes that grant the administration or specific agencies some discretion-to be subsequently respected by administrative courts-in the interpretation of indefinite legal terms in complex technical or economic matters. ${ }^{32}$ One should finally note that said courts can decide cases on the merits.

28. McLean v. Exec. Dir. of the British Columbia Sec. Comm'n, [2013] 3 S.C.R. 895, paras. 32-33, 38 (Can.) (citations omitted). For a critical view on this approach, see Paul Daly, Unreasonable Interpretations of Law, 66 SUP. CT. L. REV. (2D) 233, 248-50 (2014) [hereinafter Daly, Unreasonable Interpretations of Law].

29. Regarding Germany, see, for example, Oster, supra note 4, at 1271-73; Hoffmann-Riem, supra note 4, at 744-46. Regarding Switzerland, see, for example, PiERRE MOOR, AlEXANDRE FlÜCKIGER \& VinCENT MARTENET, DROIT ADMINISTRATIF [ADMINISTRATIVE LAW] 749-54 (3d ed. 2012).

30. Regarding Germany, see, for example, Manfred Aschke, $\S 40$, in BECK'SCHER ONLINE-KOMMENTAR VWVFG [BECK ONLINE COMMENTARY OF THE ADMinisTRATIVE PROCEDURE ACT] ๆ 102-03 (Johann Bader \& Michael Ronellenfitsch eds., 50th ed. 2021); ROLF WANK, DIE AUSLEGUNG VON GESETZEN [THE INTERPRETATION OF LAWS] 52 53 (6th ed. 2015); Eifert, supra note 9, at 339.

31. Bundes-Verfassungsgesetz [B-VG] [CONSTItution] BGBL No. 1/1930, art. 130, I 3, (Austria) (reinstated in 1945, with subsequent amendments) translated in https://www.constituteproject.org/constitution/Austria_2013.pdf?lang=en) (last visited Sept. 25, 2020) [https://perma.cc/FVK5-4G6L] (archived Sept. 25, 2020).

32. See, e.g., Michael Mayrhofer, Administrative Spielräume und die Rolle der Heilmittel- Evaluierungs-Kommission bei der Aufnahme eines Arzneimittels in den Erstattungskodex [Administrative Scope and Role of the Pharmaceutical Evaluation Commission in Including a Drug in the Reimbursement Code], 2016 JoURNAL FÜR 
In the Czech Republic, ambiguous statutory terms might have led to some deference from courts in the past, but the tendency goes towards full judicial review of the interpretation of such terms. ${ }^{33} \mathrm{In}$ Denmark, courts normally do not defer to the administrative interpretation of a statute, but they may sometimes be more reluctant to conduct an in-depth review of the interpretation chosen by an agency when a provision of statute is formulated very broadly. ${ }^{34}$ In Japan, courts often admit that administrative bodies may hold a primary decision-making power and that courts may only review the reasonableness of these decisions. ${ }^{35}$ It is, however, neither theoretically nor empirically established whether the interpretation of statutes by administrative bodies is also embodied in this attitude. Indeed, agency discretion may arise from indefinite concepts, ${ }^{36}$ but judicial deference relates especially to fact-finding, the application of a statutory concept in a specific factual context, or some procedural decisions, ${ }^{37}$ but not so much to the interpretation of a statute. Japanese courts have never officially adopted a Chevron-type deference. In Poland, some administrative discretion may result from the interpretation of vague statutory terms, ${ }^{38}$ but a doctrine of judicial deference to administrative interpretation of statutes has not yet been developed by Polish courts. ${ }^{39}$

In sum, the provision(s) of a statute at issue can reasonably be interpreted in various ways. ${ }^{40}$ Of course, the difference between clarity and ambiguity is equivocal and is itself a question of interpretation. ${ }^{41}$

Medizin und GesundheitsRecht [J. Med. \& Health L.] 54, 57 (Austria); Stefan Storr, Prüfungsmaßstab der Verwaltungsgerichte [Administrative Tribunals' Standards of Review], 2013 ZEITSCHRIFT FÜR VERKHERSRECHT [J. TRAFFIC L.] 248, 441 (Ger.).

33. See Nejvyšší správní soud Ceské republiky 22.4.2014 (NSS) [Decision of the Supreme Administrative Court of Apr. 22, 2014], čj. 8 Azs 37/2011-154, ๆ 24 (Czech). See also Zdenek Kühn \& Josef Staša, Deference to the Administration in Judicial Review in the Czech Republic, in DEFERENCE TO THE ADMINISTRATION IN JUDICIAL REVIEW, supra note 16 , at $133,139-40$.

34. See Bent Ole, Gram Mortensen \& Frederik Waage, Deference to the Administration in Judicial Review in Denmark, in DEFERENCE TO THE ADMINISTRATION IN JUDICIAL REVIEW, supra note 16, at 157, 161.

35. See Norikazu Kawagishi, Deference to the Administration in Judicial Review in Japan, in DEFERENCE TO THE ADMINISTRATION IN JUdICIAL REVIEW, supra note 16, at 295, 299-305.

36. See id. at 301-02.

37. See id. at $304-05$.

38. See Zbigniew Kmieciak \& Joanna Wegner, Deference to the Public Administration in Judicial Review: A Polish Perspective, in DefEREnCE to the ADMINISTRATION IN JUDICIAL REVIEW, supra note 16, at 363, 375-76.

39. See id. at $373-77$.

40. On this issue, see, for example. Jeffrey Barnes, Statutory Interpretation and Administrative Law, in MODERN ADMINISTRATIVE LAW IN AUSTRALIA: CONCEPTS AND CONTEXT 119, 133-39 (Matthew Groves ed., 2014).

41. See, e.g., AdRIAN VermeUle, Mechanism of Democracy: Institutional DESIGN WRIT SMALL 150 (2007). 
The presence of ambiguity, vagueness, or broadness may lead to at least two admissible or defensible interpretations of a statute in light of the applicable methods and canons of construction used by courts and, as the case may be, administrative bodies. ${ }^{42}$ In brief, the statute allows a margin of interpretation or construction. ${ }^{43}$

It is, however, argued that "[a]mbiguity should not be allowed to become the gateway to deference" and that "[t]he proper gateway is the delegation of interpretive authority." ${ }^{44}$ Are these two approaches really in opposition? The principles of statutory interpretation may indeed assist "in determining the extent of the authority delegated [or, better, granted] to the administrative decision-maker." 45 Typically, in countries where judicial deference in statutory interpretation cases is accepted, statutes often do not explicitly grant agencies or other administrative bodies an interpretive authority. ${ }^{46}$ The grant-if anyof some or all of this authority may inter alia result from the ambiguity, unclearness, vagueness, broadness, or indefiniteness of legal terms. Consequently, the "modest role for the principles of statutory interpretation in identifying rather than circumscribing administrative autonomy" 47 determines whether a statute is ambiguous, unclear or vague, or contains an indefinite legal term. This does not mean that the principles of statutory interpretation are "designed to identify ambiguity"; they are indeed "designed to resolve it." 48 But the best answer to a legal question and to the allocation of interpretive authority may sometimes have to go through a preliminary assessment of ambiguity, unclearness, vagueness, or indefiniteness.

42. On this issue, see, for example, Daly, Deference on Questions of Law, supra note 14, at 699-700. Regarding Germany, see, for example, Eifert, supra note 9, at 33839.

43. A distinction between "interpretation" and "construction" is not made here in this context, but scholars in the United States recently based their reflections on this distinction. The first concept is supposed to call "for discerning the meaning of a statute," and the second one "for determining the legal effect of the statute, through implementation rules, specification, and other devices." See generally Lawrence B. Solum \& Cass R. Sunstein, Chevron as Construction, 105 CoRnell L. REv. 1465, 1468 (2020). In this Article, "interpretation" is used in a broad sense that encompasses the "construction" of open-textured words such as "harm." On the notion of "constructional choice," regarding Australia, see Janina Boughey, The Case for "Deference" to (Some) Executive Interpretations of Law, in INTERPRETING EXECUTIVE POWER 34, 36, 53 (Janina Boughey \& Lisa Burton Crawford eds., 2020).

44. Daly, Unreasonable Interpretations of Law, supra note 28, at 268.

45. Id. at 267 .

46. On this issue, see $i d$. at 267 ("A reviewing court's approach must be holistic: it should not focus on one clause or one statutory provision in isolation, but must strive to understand the regulatory framework created by the whole of the statute." (footnote omitted)).

47. Id. at $269-70$.

48. Id. at 254 . 
The point that deference should not become the gateway to further deference is nevertheless taken, as courts should not assess ambiguity or unclearness in itself, but the existence of a margin of interpretation in light of the applicable methods and canons of construction. This approach is more flexible and gradual ${ }^{49}$ than the one-too schematic and binary - that consists of determining whether or not a statute is ambiguous. ${ }^{50}$ Judges are not supposed to either unnecessarily define the exact extent of the margin, or list all the admissible or reasonable interpretations of the statute provision at hand. ${ }^{51}$ Moreover, by finding the existence of a margin of interpretation, they do not have to indicate their preference for a different interpretation of the statute than the one chosen by the administrative body; they simply accept the latter because it remains within said margin. ${ }^{52}$

\section{B. International, Constitutional, Statutory, and Other Constraints}

Deference presents itself within a constitutional and statutory framework. Ceteris paribus, the more constraining the latter, the less relevant the debate on judicial deference in statutory interpretation cases becomes. International constraints may also come into play, most notably regarding the right to a fair trial guaranteed by Article 14 of the International Covenant on Civil and Political Rights, Article 6 of the European Convention on Human Rights (ECHR), ${ }^{53}$ Article 8 of the American Convention on Human Rights, or Article 7 of the African Charter on Human and Peoples' Rights. ${ }^{54}$ General principles such as the rule of law may impose other constraints.

49. On this question, focusing on Canada, see RUTH SUlLIVAN, SULLIVAN ON THE CONSTRUCTION OF STATUTES 25 (6th ed. 2014) ("Texts are not either plain or ambiguous; rather they are more or less plain and more or less ambiguous. The factors that justify outcomes in statutory interpretation are multiple, involving inferences about meaning and intention derived from the text, non-textual evidence of legislative intent, specialized knowledge, 'common sense' and legal norms. These factors interact in complex ways.”). Regarding the United States, see Nicholas R. Bednar \& Kristin E. Hickman, Chevron's Inevitability, 85 GEO. WASH. L. REV. 1392, 1446 (2017).

50. On this issue, see, for example, JoRDÃo, supra note 16, at 233-35, 248-49.

51. Regarding Canada, see a recent decision of the Supreme Court, Canada (Minister of Citizenship and Immigration) v. Vavilov, [2019] S.C.C. 65, para. 83 (“[A] court applying the reasonableness standard does not ask what decision it would have made in place of that of the administrative decision maker, attempt to ascertain the 'range' of possible conclusions that would have been open to the decision maker, conduct a de novo analysis or seek to determine the 'correct' solution to the problem.").

52. On this issue, see VERMEULE, supra note 41, at 156-65. Regarding the United States, see Little Sisters of the Poor Saints Peter and Paul Home v. Pennsylvania, 140 S. Ct. 2367, 2400 (2020) (Kagan, J., concurring in the judgment) ("If I had to, I would of course decide which is the marginally better reading [of the statute]. But Chevron deference was built for cases like these.").

53. European Convention on Human Rights art. 6, Nov. 4, 1950, E.T.S. 5.

54. African Charter on Human and Peoples' Rights art. 7, June 27, 1981, 1520 U.N.T.S. 26363. 
Two types of constitutional constraints limit the possibility of judicial deference in statutory interpretation cases. Firstly, the role of the judiciary is defined in general terms in many constitutions. The relevant constitutional provisions may prevent any general or broad deference from the courts reviewing administrative decisions. ${ }^{\mathbf{5 5}}$ Secondly, constitutional procedural safeguards may guarantee the right to appeal these decisions to a court which can fully review the merits of each case by assessing all relevant facts in addition to the correct interpretation of the law and its application to the facts. ${ }^{56} \mathrm{In}$ the United States, deference doctrines-Chevron in particular-are under fire by various scholars, and deference claims are met with increased skepticism in courts; notably, the argument is made that due process rights come into play and restrict a court's ability to defer to agency interpretation of statutes. ${ }^{57}$

Statutory constraints can typically require courts to fully assess the merits of a case and prevent them from using any type of deference to administrative interpretation of statutes. ${ }^{58}$ In the United States, a 2018 bill adopted in the state of Arizona forbids all judicial deference in constitutional interpretation or interpretation of statutes regarding most of the state's own agencies:

[i]n a proceeding brought by or against the regulated party, the court shall decide all questions of law, including the interpretation of a constitutional or statutory provision or a rule adopted by an agency, without deference to any previous determination that may have been made on the question by the agency. ${ }^{\mathbf{5 9}}$

\section{The Legislature's Intent or Assent}

Judicial deference to administrative interpretation of statutes seems to relate to the relationship between the judiciary and the executive branches. However, the legislature is also a key player

55. See infra Parts V.C, VI.A.

56. See infra Parts V.D, VI.A.

57. See, e.g., Philip Hamburger, Chevron Bias, 84 Geo. WASH. L. REV. 1187 (2016). But see Gillian E. Metzger, The Roberts Court and Administrative Law, 2019 SuP. CT. REV. 1, 4 (2020) (“[F]or all of its alarmism about bureaucrats running amok and assertions that the contemporary administrative state violates the constitutional order, the Roberts Court hadn't yet pulled back significantly on administrative governance in practice.").

58. Regarding the United States, see, for example, The Chevron Doctrine: Constitutional and Statutory Questions in Judicial Deference to Agencies: Hearing Before the Subcomm. on Regulatory Reform, Commercial \& Antitrust Law of the H. Comm. on the Judiciary, 114th Cong. 28 (2016) (statement of Jonathan Turley, Shapiro Professor of Public Interest Law, George Washington University) [hereinafter Statement of Jonathan Turley] ("Because the [Chevron] doctrine is based on assumption of delegated authority, Congress can aggressively move to limit such deference....”).

59. H.B. 2238, 53rd Leg., 2d Reg. Sess., § 12-910(E) (Ariz. 2018). 
here. ${ }^{60}$ It may widely forbid any judicial deference, as the state of Arizona recently did, or, on the contrary, expressly authorize it.

Express authorization is seldom granted and must in any case comply with applicable international, constitutional, statutory and other constraints. The second sentence of Section 71(5) of the German Act against Restraints of Competition is an interesting example in this regard, as it states that "[t]he evaluation of the general economic situation and trends by the competition authority shall not be subject to review by the court." 61

In the vast majority of cases, statutes do not explicitly address the issue of judicial deference but do not expressly preclude it either. ${ }^{62}$ Scholars and courts ${ }^{63}$ in some countries have developed various theories according to which the legislature is supposed to have accepted judicial deference and this particular setting of the separation of powers principle or of the concept of checks and balances.

In the United States, the Chevron doctrine especially supposes that Congress has delegated or granted agencies the authority to act with the force of law. ${ }^{64}$ In Germany, it is based on the so-called "normative authorization doctrine" (normative Ermächtigungslehre). ${ }^{65}$

60. From a comparative perspective, see Peter Lindseth, Judicial Review in Administrative Governance: A Theoretical Framework for Comparative Analysis, in JUDICIAL REVIEW OF ADMINISTRATIVE DISCRETION, supra note 16, at 175, 188. See also, with a special focus on Canada, DALY, supra note 16, at 36-69 (concluding, on page 69, that "a holistic approach, which requires a proper consideration of the relevant statutory provisions, is necessary to ascertain the extent of the delegation of power"). Regarding Germany, see, for example, Oster, supra note 4, at 1273-75; Eberhard Schmidt-Aßmann, Artikel 19 Abs. 4 [Article 19 Sect. 4], in GrundGeSETZ: KommEnTAR [BASIC LAW: COMMENTARY] ๆ 184-86 (Theodor Maunz \& Günter Dürig eds, 2020). Regarding the United States, see, for example, Cass R. Sunstein, Chevron As Law, 107 GEO. L.J. 1613, 1634-35 (2019) ("The initial question, and perhaps the only question, is: What has Congress required?").

61. Gesetz Gegen Wettbewerbsbeschränkungen [GWB] [Act Against Restraints of Competition], June 26, 2013, BUNDESGESETZBLATT [BGBL I] § 71(5) (Ger.), translated at http://www.gesetze-im-internet.de/englisch_gwb/ (last visited Sept. 23, 2020) [https://perma.cc/QJW2-8R7T] (archived Sept. 20, 2020); see also Telekommunikationsgesetz [TKG] [German Telecommunications Act], July 25, 1996, BUNDESGESETZBLATT [BGBL I] $§ \quad 10(2) \quad$ (Ger.), translated in https://germanlawarchive.iuscomp.org/?p=692 (last visited Sept. 23, 2020) [https://perma.cc/99JX-LR4H] (archived Sept. 23, 2020).

62. Regarding Germany and the U.S., see Oster, supra note 4, at 1284; KLAAS Bosch, DIE KONTROLLDICHTE DER GERICHTLICHEN ÜBERPRÜFUNG VON MARKTREGULIERUNGSENTSCHEIDUNGEN DER BUNDESNETZAGENTUR NACH DEM TElekommunikationsgesetz [The DENSity of CONTROL OF Judicial REVIEW of MARKET REGULATION DECISIONS OF THE FEDERAL NETWORK AGENCY ACCORDING TO THE TELECOMMUNICATIONS ACT] 46-50 (2010); Hoffmann-Riem, supra note 4, at 746.

63. From a comparative perspective, see Zhu, supra note 18, at 7 ("Deference is a legal concept developed by judge made law." (emphasis in original)).

64. United States v. Mead Corp., 533 U.S. 218, 226-27 (2001).

65. See, e.g., Aschke, supra note 30, ๆ 103; Hoffmann-Riem, supra note 4, at 736, 743-44; Schmidt-Aßmann, supra note 60, ๆ 185-87a; Andreas Voßkuhle, Entscheidungsspielräume der Verwaltung (Ermessen, Beurteilungsspielraum, 
These American and German approaches are comparable, though they differ conceptually, and their doctrinal importance is not the samecentral in the United States, at least theoretically, more peripheral in Germany. ${ }^{\mathbf{6}}$ In Switzerland, a similar approach to the one existing in Germany can be observed in several Federal Tribunal cases. ${ }^{67}$ In the Netherlands, the law may grant a margin of discretion in statutory interpretation to an agency. ${ }^{68}$ In each case, courts must assess whether the legislature aimed at granting discretionary powers to an independent authority, for example to the Dutch Authority for Consumers and Markets. ${ }^{69}$ The particular expertise of the authority will be an important justification for such a legislative choice. ${ }^{70}$ Two comments must, however, be made regarding the Netherlands. On the one hand, the principle of effective judicial protection tends, ceteris

planerische Gestaltungsfreiheit) [Scopes for Decision-Making of the Administration Discretion, Latitude of Judgment, Freedom of Planning], 2008 JURISTISCHE SCHULUnG [LEGAL TRAINING] 117, 118. For an extensive and comparative study (Germany-U.S.) of this issue, see Oster, supra note 4.

66. See Oster, supra note 4, at 1295 ("Both doctrines are based on the assumption that it is the legislature who decides whether courts have to grant deference. However, the normative authorization theory has a further prerequisite compared to the Chevron doctrine. According to Chevron, the authorization of the agency lies in the ambiguity of the statute. German courts require an indefinite legal term and in addition an explicit or implicit legislative authorization to interpret the term .... The difference between the second requirement of the German normative authorization doctrine and the U.S. Chevron doctrine is marginal, because many of the requirements of the German 'step two' are already included in the rationales of Chevron, e.g. the agency expertise or the procedure.").

67. The Federal Tribunal is Switzerland's highest court, the Bundesgericht, the Tribunal fédéral or the Tribunale federale. See Tribunal fédéral [TF] Mar. 21, 2014, 140 ARRÊTS DU TRIBUNAL FÉDÉRAL [ATF] I 201, 205-06 (Switz.); Bundesgericht [BGer] [Federal Supreme Court] Oct. 7, 2009, 135 ENTSCHEIDUNGEN DES SCHWEIZERISCHEN BunDESGERICHTS [BGE] II 384, 389-90 (Switz.); Bundesgericht [BGer] Apr. 21, 2006, 132 ENTSCHEIDUNGEN DES SCHWEIZERISCHEN BUNDESGERICHTS [BGE] II 257, 262-63. On this case law, see TANQUEREL, supra note 6, at 218-19, 222-23, who approves of the Federal Tribunal's approach.

68. See Saskia Lavrijssen \& Maartje de Visser, Independent Administrative Authorities and the Standard of Judicial Review, 2 UTRECHT L. REV. 111, 114 (2006).

69. See Saskia Lavrijssen \& Fatma Çapkurt, Who Guards the Guardians? Judicial Oversight of the Authority Consumer and Market's Energy Regulations in the Netherlands, in JUDICIAL REVIEW OF ADMINISTRATIVE DisCRETION, supra note 16, at 133, 140-41.

70. See Tom Barkhuysen \& Michiel L. van Emmerik, Deference to the Administration in Judicial Review: The Case of the Netherlands, in DEFERENCE TO THE ADMINISTRATION IN JUDICIAL REVIEW, supra note 16, at 327, 339-41; Arnout P. Klap, Rechterlijke toetsing aan vage normen in Nederland en Duitsland [Judicial Review of Vague Norms in the Netherlands and Germany], in TOETSING AAN VAGE NORMEN IN HET Nederlandse, Duitse, Engelse en Franse Recht [Review of Vague Norms in DUTCH, German, EnGLISH AND FREnch LAW] 1, 1 (Arnout P. Klap, F. Taco Groenewegen \& Jean Reiner van Angeren eds., 2014) (drawing a distinction between vague norms that entail a weighing of interests, those that demand an evaluation of future events, those that require specific expertise and those with a supranational character, as well as combinations thereof). 
paribus, to strengthen the intensity of judicial review. ${ }^{71}$ On the other hand, and by contrast to a certain extent, courts sometimes defer to the interpretation of vague legal notions by independent specialized authorities even when courts are entitled and supposed to carry out a full review of the law. ${ }^{72}$

In Canada, a recent landmark decision of the Supreme Court ${ }^{73}$ rightfully puts the focus on the legislature's intent with respect to the applicable standard of review, which then has implications on the question of judicial deference to administrative interpretation of statutes. Nevertheless, it is debatable whether the Court correctly presumed ${ }^{74}$ or assessed the intent, ${ }^{75}$ and especially whether the intent was not too generally and schematically determined. ${ }^{76}$ Has the Supreme Court itself applied the "modern principle" of statutory interpretation to which it is referring, ${ }^{77}$ while implicitly interpreting all the relevant and affected statutes? In any event, this decision does

71. See Lavrijssen \& Çapkurt, supra note 69, at 154-68; Barkhuysen \& van Emmerik, supra note 70, at 336-41.

72. See Lavrijssen \& Çapkurt, supra note 69, at 145-48, 159-60 and the examples mentioned within.

73. See generally Canada (Minister of Citizenship and Immigration) v. Vavilov, 2019 S.C.C. 65. In this case, the Supreme Court ruled, on the basis of its interpretation of the Canadian Citizenship Act, that a person born in Canada to parents who were undercover Russian spies is a Canadian citizen.

74. Id. para. 23 ("Where a court reviews the merits of an administrative decision (i.e., judicial review of an administrative decisions [sic] other than a review related to a breach of natural justice and/or the duty of procedural fairness), the standard of review it applies must reflect the legislature's intent with respect to the role of the reviewing court, except where giving effect to that intent is precluded by the rule of law. The starting point for the analysis is a presumption that the legislature intended the standard of review to be reasonableness.").

75. Id. para. 17 ("The presumption of reasonableness review can be rebutted in two types of situations. The first is where the legislature has indicated that it intends a different standard or set of standards to apply. This will be the case where the legislature explicitly prescribes the applicable standard of review. It will also be the case where the legislature has provided a statutory appeal mechanism from an administrative decision to a court, thereby signaling the legislature's intent that appellate standards apply when a court reviews the decision. The second situation in which the presumption of reasonableness review will be rebutted is where the rule of law requires that the standard of correctness be applied.”).

76. Id. para. 246 (Abella \& Karakatsanis, JJ., concurring) ("In reality, the majority's position on statutory appeal rights, although couched in language about 'giv[ing] effect to the legislature's institutional design choices', hinges almost entirely on a textualist argument: the presence of the word 'appeal' indicates a legislative intent that courts apply the same standards of review found in civil appellate jurisprudence.").

77. Id. paras. 117-18. On the "modern principle," see, however, Stéphane Beaulac \& Pierre-André Côté, Driedger's "Modern Principle" at the Supreme Court of Canada: Interpretation, Justification, Legitimization, 40 REVUE JURIDIQUE THÉMIS [THÉMIS L. REV.] 131, 171 (2006) (“The construction of statutes constitutes such a complex process, especially in the harder cases that tend to end up in courts, that it is extremely difficult to state the proper approach to interpretation in but a few words, if it can be done at all.”). 
not close the discussion, as it will be followed by other judicial decisions and may give rise to a reaction by the legislature. If it is not satisfied by the approach followed by the Supreme Court, the legislature can ex post and pro futuro change current statutory provisions within the constraints of the rule of law and enact new statutes taking this case law into consideration. Thus, the legislature retains a form of control on this issue, with the caveat that each statutory provision is then interpreted by administrative bodies and courts-a process the legislature does not control.

In brief, the legislature must assent to judicial deference or, in other words, enable courts to defer to administrative statutory interpretation-passively and ex post ${ }^{78}$ at the very least. This principle seems to be common to several countries, although its conceptualization differs from one to the next. In short, the legislature has the control over this issue, as it can open or close the door to judicial deference to administrative statutory interpretation. Its intent or assent is, however, often at best implicit, which means that courts have to determine whether and, if so, to what extent they should or can defer to administrative bodies. ${ }^{79}$

Finally, in a given country, administrative decision-makers that have interpretive authority may even benefit from a "presumption of deference," 80 to the point where one may consider that judicial

78. Regarding the United States, see William N. Eskridge Jr. \& Lauren E. Baer, The Continuum of Deference: Supreme Court Treatment of Agency Statutory Interpretations from Chevron to Hamdan, 96 GEO. L.J. 1083, 1188 (2008) ("[A] longstanding agency interpretation that regulated parties have internalized and that Congress has acquiesced in should rarely be overturned ...." (emphasis in original)).

79. From a comparative perspective, see, for example, JoRDÃo, supra note 16, at $345,571-72$.

80. Regarding Canada, the majority of the Supreme Court in the recent Vavilov decision held that all administrative decisions should presumptively be reviewed on the reasonableness standard and, thus, receive judicial deference, unless either legislative intent or the rule of law requires otherwise. 2019 S.C.C. 65 paras. 10, 23-72. When applicable, this standard also covers questions of statutory interpretation-provided, in particular, that they are not "general questions of law of central importance to the legal system as a whole," $i d$. paras. 58-62-and means that administrative decisions are allowed to stand as long as they are "reasonable." In other words, the "presumption of reasonableness review" corresponds to a "presumption of deference." See, e.g., Steven Mason, Brandon Kain, Joanna Nairn, Richard Lizius \& James S.S. Holtom, The Supreme Court of Canada Simplifies the Standard of Review Analysis in Historic Super Bowl Trilogy, MCCARTHY TÉTRAULT LLP (Dec. 19, 2019), https://www.mccarthy.ca/en/insights/articles/touchdown-supreme-court-canadasimplifies-standard-review-analysis-historic-super-bowl-trilogy [https://perma.cc/2HZ6EULL] (archived Sept. 24, 2020) (using both concepts interchangeably). The Vavilov decision strengthened the presumption but, at the same time, created a large exception in the case of statutory appeals. In this respect, two Justices considered, in Vavilov, that this decision greatly erodes the presumption of deference, 2019 S.C.C. 65 paras. 199-201 (Abella \& Karakatsanis, JJ., concurring), established in Alberta. See Alberta (Information and Privacy Commissioner) v. Alberta Teachers' Ass'n [2011] S.C.R. 654, 656 para. 34 (" $[\mathrm{U}]$ nless the situation is exceptional, the interpretation by the tribunal of 
"intervention should be the exception rather than the norm." 81 Such an approach may, however, be difficult to reconcile with the constitutional role of courts and procedural safeguards in many countries. ${ }^{82}$ In the European context, such a presumption is incompatible with Article 6 of the European Convention of Human Rights when this human right is applicable. ${ }^{83}$

\section{The CAse for Judicial Deference}

In several countries, various aspects of administrative legitimacy and of the principle of separation of powers (subpart A) as well as the optimal allocation of limited resources (subpart B) may justify judicial deference to administrative interpretation of statutes, at least in certain cases. Humility, honesty, and transparency from the courts (subpart C) as well as other considerations (subpart D) may also explain some form of judicial deference.

\section{A. Administrative Legitimacy and the Separation of Powers}

The legitimacy of agencies and other administrative bodies is based on several factors. One of the-if not the-primary bases for their legitimacy is their expertise - and that of their officials and staff (1). Their political accountability (2) or their independence (3) and the political discretion that may be linked to certain areas of public activity (4) also deserve specific mention. This list is not exhaustive.

\section{Expertise}

Some government organizations, like agencies, are typically specialized in a certain field. Their officials and staff possess specific expertise and experience in the relevant field. Experience may lead to expertise (the "catch-all" notion in this respect, as it includes experience in this context), according to the terminology used in this Article. A statute's interpretation raises legal issues, but also non-legal ones of which courts may have limited knowledge. ${ }^{84}$ In the United

\footnotetext{
its home statute or statutes closely connected to its function should be presumed to be a question of statutory interpretation subject to deference on judicial review."). On this presumption before Vavilov, see Daly, Unreasonable Interpretations of Law, supra note 28 , at 251 .

81. Daly, Unreasonable Interpretations of Law, supra note 28, at 270.

82. See infra Parts V.C-D, VI.A.

83. See infra Part V.D.

84. From a comparative perspective, see, for example, JORDÃo, supra note 16, at 86-124; Michael C. Tolley, Judicial Review of Agency Interpretation of Statutes: Deference Doctrines in Comparative Perspective, 31 POL'Y STUD. J. 421, 421 (2003) ("The
} 
States, the specific expertise of specialized agencies contributes to justify both the Chevron deference, doctrine, test, or space, ${ }^{85}$ whichwhen applicable-requires a federal court to defer to an agency's interpretation of an ambiguous statutory provision if this interpretation is considered reasonable, ${ }^{86}$ and the Skidmore deference, doctrine, test, or weight, which allows a federal court to determine the appropriate level of deference for each case based on "the thoroughness evident in [the agency's] consideration, the validity of its reasoning, its consistency with earlier and later pronouncements, and all those factors which give it power to persuade, if lacking power to control."87 A high level of judicial deference may take place when scientific knowledge is required, bearing in mind that this does not mean absence of review; mutual efforts must be made in order to establish rigorous analytical yardsticks to guide the administrative decision process and to provide courts with a framework against which to review the administrative decisions. ${ }^{88}$

In certain countries such as Canada, even administrative decisions involving constitutional values may be subject to deference, since "[a]n administrative decision-maker exercising a discretionary power under her home statute, has, by virtue of expertise and specialization, particular familiarity with the competing considerations at play in weighing Charter [of Rights and Freedoms]

general idea is that specialist agencies are often in a better position than courts to resolve the ambiguities, and interpreting a statute in a way that promotes effective public policy may depend more on the expertise of the agency and less on the limited knowledge and modes of reasoning employed by courts.").

85. See generally Peter L. Strauss, "Deference" is Too Confusing - Let's Call Them "Chevron Space" and "Skidmore Weight", 112 CoLUM. L. REV. 1143 (2012).

86. Chevron, U.S.A., Inc. v. Nat. Res. Def. Council, Inc., 467 U.S. 837, 842-43 (1984); see, e.g., The Chevron Doctrine: Constitutional and Statutory Questions in Judicial Deference to Agencies: Hearing Before the Subcomm. on Regulatory Reform, Commerical \& Antitrust Law of the H. Comm. on the Judiciary, 114th Cong. 69 (2016) (statement of Emily Hammond, Associate Dean for Public Engagement \& Professor of Law, Geo. Wash. Univ. L. Sch.) [hereinafter Statement of Emily Hammond] ("Agencies have experience with the statutes they administer and the challenges that arise under the applicable regulatory regimes. Relative to the courts, agencies also have superior expertise, particularly with respect to complex scientific or technical matters.").

87. Skidmore v. Swift \& Co., 323 U.S. 134, 140 (1944); see, e.g., The Chevron Doctrine: Constitutional and Statutory Questions in Judicial Deference to Agencies: Hearing Before the Subcomm. on Regulatory Reform, Commercial \& Antitrust Law of the H. Comm. on the Judiciary, 114th Cong. 62 (2016) (statement of Richard J. Pierce, Lyle T. Alverson Professor of Law, Geo. Wash. Univ. L. Sch.) ("The [Skidmore] test was based on the comparative advantage of specialized agencies over generalist courts because of agencies' greater subject matter expertise and greater experience in implementing a statutory regime. The results of applications of the test suggest that it is deferential to agency decisions.").

88. Regarding the United States, see Elizabeth Fisher, Pasky Pascual \& Wendy Wagner, Rethinking Judicial Review of Expert Agencies, 93 TEx. L. REV. 1681, 1703 (2015); see also Emily Hammond Meazell, Super Deference, the Science Obsession, and Judicial Review as Translation of Agency Science, 109 MiCH. L. REV. 733, 756 (2011). 
values." ${ }^{89}$ However, "constitutional questions" as such "require a final and determinate answer from the courts." 90

In some countries where there is very little or no judicial deference to administrative statutory interpretation, it is interesting to note that expertise may not be regarded as a primary characteristic of public administration. In Australia for instance, "expertise is a special characteristic of some administrative decision-makers rather than an assumed characteristic of public administration generally," the upper echelons of the public service having been "predominantly populated by "generalists." 91 One should be careful before drawing institutional conclusions from this observation, which is otherwise debatable. Still, the Australian High Court has held that "there is very limited scope for the notion of 'judicial deference' with respect to findings by an administrative body of jurisdictional facts," 92 but interpretation of the law is considered as a separate matter. Indeed, the interpretation of the law by the judiciary and judicial control over administrative interpretation are seen as "fundamental" by the High Court. ${ }^{93}$ Australian case law may actually give some room to various forms of judicial deference especially relating to fact-finding and applying the law to facts ${ }^{94}$ due to, for instance, the specific expertise of certain administrative bodies, ${ }^{95}$ but the High Court has declined to adopt the

89. Doré v. Barreau du Québec [2012] 1 S.C.R. 395, 397 para. 47 (Can.); see also Loyola High School v. Att'y Gen. of Québec [2015] 1 S.C.R. 613, paras. 4, 35-42 (Can.). On this Canadian case law, see LEWANS, supra note 16, at 180-83; see also Claudia Geiringer, Process and Outcome in Judicial Review of Public Authority Compatibility with Human Rights: A Comparative Perspective, in The Scope AND InTENSITY of SUBSTANTIVE REVIEW 329, 349-57, 359-60 (Hanna Wilberg \& Mark Elliott eds., 2015).

90. Canada (Minister of Citizenship and Immigration) v. Vavilov, [2019] S.C.C. 65 para. 55 .

91. Peter Cane, Judicial Control of Administrative Interpretation in Australia and the United States, in THE SCOPE AND INTENSITY OF SUBSTANTIVE REVIEW, supra note 89, at 215, 222; see also Lisa B. Crawford, The Rule of Law in the Age of Statutes, 48 FED. L. REV. 159, 182 (2020) ("Undoubtedly, there are those within the executive branch who have worked at the coalface of the relevant sphere of government activity for many years. The legislation that governs that field may have incorporated the technical language and concepts that these actors work with every day (but which may be incomprehensible to a judge or generalist lawyer). But the now corpulent administrative state is surely also staffed, in no small part, by low-grade and transitory staff who have no great expertise in the field of government activity in which they are involved.").; Mark Aronson, Should We Have a Variable Error of Law Standard?, in THE SCOPE AND INTENSITY OF SUBSTANTIVE REVIEW, supra note 89, at 241, 261.

92. Corp. of the City of Enfield v Dev. Assessment Comm'n [2000] 199 CLR 135 para. 59 (Austl.).

93. Id. paras. $40,43,45$.

94. See Stephen Gageler, Deference, 22 Australian J. ADMIN. L. 151, 154-56 (2015); Alan Freckelton, The Concept of 'Deference' in Judicial Review of Administrative Decisions in Australia - Part 1, 73 AUSTRALIAN INST. OF ADMIN. L.F. 52, 62--67 (2013).

95. See Fleur Kingham, Deference to the Administration in Judicial Review in Australia, in DEFERENCE TO THE ADMINISTRATION IN JUDICIAL REVIEW, supra note 16, at 39, 61-62; Freckelton, supra note 94, at 64-66; Barnes, supra note 40, at 133. 
Chevron doctrine ${ }^{96}$ especially because of the Australian courts' constitutional role. ${ }^{97}$

The deliberative process that takes place in many agencies or other administrative bodies, organized as commissions for instance, is also supposed to grant particular legitimacy to the decisions made and to the interpretation of statutes on which they are based. However, a deliberative process also occurs in courts when decisions are taken by a panel of judges, and an individual judge may interact with her clerks. Furthermore, legitimacy resulting from the administrative deliberative process actually depends on the expertise and experience of the people involved. ${ }^{98}$ Diversity in this respect can broaden and enrich the interpretation of the statute. In principle, interdisciplinarity with regard to non-legal questions does not exist in courts, at least not to the same degree.

\section{Political Accountability}

In some countries, administrative bodies such as agencies may not be independent from government or may only be independent to a limited extent; as a result, the executive is more clearly held accountable for their decisions. Political interference may, therefore, exist or, depending on the jurisdiction, become inevitable. However, political accountability is seen as a reinforcing factor of administrative legitimacy compared to the legitimacy of the courts. ${ }^{99}$ Accordingly, some judicial deference in statutory interpretation cases would be justified. The "democratic basis for distributing legal authority to administrative officials" ${ }^{100}$ and even the separation of powers ${ }^{\mathbf{1 0 1}}$ are also invoked in support of judicial deference regarding administrative decisions.

96. Enfield, 199 CLR paras. 40-42; see Kingham, supra note 95, at 51-52, 83; Gageler, supra note 94, at 155-56.

97. See Kingham, supra note 95, at 83; Gageler, supra note 94, at 156; Barnes, supra note 40 , at 131,138 . However, some authors now make the case for judicial deference to some executive interpretations of law with constitutional arguments that do not rest on new case law or legislation. See Boughey, supra note 43, at 41-53 (“[T]here are compelling arguments for judges to take expert administrators' interpretations of the legislation they are charged with administering seriously and prefer those interpretations where there is a constructional choice to make." (quotation from page 53)); see also John McMillan, Statutory Interpretation and Deference: An Executive Perspective, in INTERPRETING EXECUTIVE POWER, supra note 43, at 24, 27-33.

98. Regarding Germany, see Bosch, supra note 62 , at 75 .

99. From a comparative perspective, see, for example, JoRDÃo, supra note 16, at 53-86. Regarding the United States, see, for example, WiLliam N. ESKRIDGE JR., INTERPRETING LAW: A PRIMER ON HOW TO READ STATUTES AND THE CONSTITUTION 28283 (2016); VERMEULE, supra note 41, at 155.

100. Regarding Canada, see, for example, LEWANS, supra note 16, at 223.

101. Regarding Switzerland, see SCHINDLER, supra note 6, at 379-80. 
Nevertheless, the risk of political influence is, ceteris paribus, higher where agencies or other administrative bodies are not independent from government. Political influence may lead them to consider elements that are irrelevant as they interpret statutes. Therefore, one could very well argue that such a risk requires an unrestricted judicial review of administrative decisions. In addition, an agency's accountability from a citizen's point of view is, at best, very indirect. In a parliamentary political system, the party or the parties in power can in principle be held accountable, ${ }^{102}$ but most voters will not cast their votes on the basis of the activities of one agency. In a presidential ${ }^{103}$ or semi-presidential political system, as in France for example, are the decisions made by an agency really an important aspect of the presidential or the parliamentary elections?

In connection with agencies' or other administrative bodies' alleged political accountability, the separation of powers principle or similar considerations are sometimes invoked in order to support judicial deference to administrative statutory interpretation. ${ }^{104}$ An ambiguous or unclear statute is supposed to raise policy issues-rather than strictly legal ones-to be addressed first and foremost by the executive. Indeed, constitutional or statutory interpretation is by no means mechanical. It is nonetheless one of the judicial tasks par excellence. ${ }^{105}$ The interpretation of statutes often involves-significant or modest-policy decisions; ${ }^{106}$ this observation eventually creates the impression that such decisions should be made by a body belonging to the executive branch rather than by a court. The initial remark is correct, the second not as much, not the least because questions of law

102. On this issue and related ones regarding the United States, see Eskridge \& Baer, supra note 78, at 1175-79. From a comparative perspective, see Robert C. Dolehide, A Comparative "Hard Look" at Chevron: What the United Kingdom and Australia Reveal About American Administrative Law, 88 TEX. L. REV. 1381, 1383, 1394 95 (2010).

103. See Dolehide, supra note 102, at 1383 ("American voters, in contrast [to voters in the United Kingdom and Australia], cannot attribute the blame or credit for administrative action quite as clearly: is Congress primarily responsible-since it passed the relevant legislation —or is the President responsible, since the Executive implements the legislation?").

104. Regarding Germany, see, for example, Oster, supra note 4, at 1273-74. 41.

105. Regarding Germany, see, for example, Hoffmann-Riem, supra note 4, at 740-

106. From a general or comparative perspective, see, for example, Reitz, supra note 4, at 286; T. R. S. Allan, Deference, Defiance, and Doctrine: Defining the Limits of Judicial Review, 60 U. TORONTO L.J. 41, 42 (2010) ("In public law, . . . questions of law are rarely pure: they come intertwined with considerations of policy and public interest remitted to other public officials to determine. In such cases, the law constitutes a boundary that the exercise of policy discretion must respect: judges should police the boundary while avoiding the temptation to step over it into the policy-making arena. The challenge is to determine precisely where the boundary lies."). Regarding the United States, see, for example, Brett M. Kavanaugh, Fixing Statutory Interpretation, 129 HARV. L. REV. 2118, 2152-54 (2016). 
cannot be neatly distinguished from questions of policy. ${ }^{107} \mathrm{~A}$ general judicial deference does not derive from this inextricable reality. It would insulate the executive branch of government from sufficient checks and balances. In other words, it would be a stretch to suggest that judicial deference in statutory interpretation cases is required by the separation of powers principle. Interpreting a criminal statute, for instance, inevitably raises questions of policy, even if criminal law provisions are, ceteris paribus, deemed to be less open to interpretation than civil or administrative law provisions, due to the strict application of the principle of legality in criminal law. However, not only but most notably, due to fundamental rights, nobody seriously argues that courts should defer to prosecutors' views or to agencies' decisions in systems where the latter have decision-making powers in criminal or quasi-criminal matters.

\section{Independence}

In other countries, many agencies are independent from government. France, with its numerous independent administrative authorities (autorités administratives indépendantes), provides an illustrative example. Independence means, inter alia, that the agencies in question do not receive instructions from government and that their president or director cannot be removed for political reasons. ${ }^{108}$ Ceteris paribus, the risk of misinterpretation of a statute due to political influence or pressure is reduced. Consequently, judicial checks could be loosened.

Independent agencies are organized as quasi-jurisdictional bodies in many countries, and, when they decide concrete cases, they follow, to an important extent, court-like proceedings. When they review agency decisions, appellate courts may take into account this institutional and procedural framework, which may lead to some deference. ${ }^{109}$ It is, however, questionable whether the deference really relates to statutory interpretation in such a context, especially when no particular agency expertise is necessary to interpret a given statutory provision.

107. LEWANS, supra note 16, at 222 (regarding the interpretation of fundamental rights); see also Mathews, supra note 26, at 185-88; The Chevron Doctrine: Constitutional and Statutory Questions in Judicial Deference to Agencies: Hearing Before the Subcomm. on Regulatory Reform, Commercial and Antitrust Law of the H. Comm. on the Judiciary, 114th Cong. 76, 84-86 (2016) (statement of Jack M. Beermann, Professor of Law and Harry Elwood Warren Scholar, Bos. Univ.); Yoav Dotan, Deference and Disagreement in Administrative Law, 71 ADMIN. L. REV. 761, 790-2 (2019).

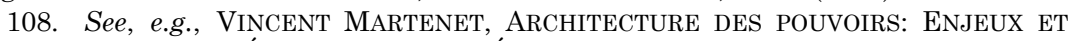
PERSPECTIVES POUR UN ÉTAT, UNE UNION D'ÉTATS ET LES NATIONS UNIES [ARCHITECTURE of Powers: Challenges and Perspectives for a State, A Union of States and The UNITED NATIONS] 9-15, 149-53 (2016).

109. See infra Part VI.A. 
On the other hand, reduced political control is sometimes seen as a strong argument in favor of unrestricted judicial review. ${ }^{110}$ The lack of political checks and balances is supposed to somehow be compensated by such a review. From this perspective, independence without political accountability and judicial deference do not mix well, but one should not forget that the nature of political control differs from the nature of judicial control. ${ }^{111}$

\section{Political Discretion}

In certain areas, decisions emanating from the executive branch are regarded as highly political and are, thus, subject to limited judicial review or are even exempt from it. The political question doctrine elaborated by the Supreme Court of the United States is well known. ${ }^{112}$ Limits may indeed be justified, but one may feel more comfortable when they are firmly grounded in a country's statutes ${ }^{113}$ or even in its constitution, as is the case in Switzerland. ${ }^{114}$

In certain cases, the political process may be regarded as the most appropriate and legitimate or even as the only conceivable avenue in order to address all issues and interests at stake and to lead to eminently political decisions. ${ }^{115}$ Accordingly, little or no room is left to judicial review. The words "separation of powers"-and not simply "separation of expertise"- seem to be adequate in this context, though political or diplomatic expertise may also explain cases of total or partial insulation of the executive branch from judicial review. ${ }^{\mathbf{1 1 6}}$

Questions raised by decisions of the legislative or executive branches, which are totally or largely immune from judicial review,

110. See infra Part V.E.

111. See id.

112. For a recent example, see Rucho v. Common Cause, 139 S. Ct. 2484, 24962508 (2019) (holding that partisan gerrymandering claims present political questions beyond the reach of the federal courts).

113. See, e.g., ROBERT H. WAGSTAFF, TERRor DETENTIONS AND THE RUlE OF LAW: US AND UK PERSPECTIVES 282 (2013) ("Parliamentary sovereignty addresses jurisdictional matters: for example, does the court have the authority to speak? Judicial deference is a subset: the court has the authority to speak, but sometimes it chooses not to do so.").

114. Constitution Fédérale [CST] [Constitution] Apr. 18, 1999, SR 101, art. 189, § 4 (Switz.) ("Acts of the Federal Assembly [Parliament] or the Federal Council [Government] may not be challenged before the Federal Supreme Court. Exceptions may be provided for by law.”).

115. From a comparative perspective, see Zhu, supra note 18, at 9. Regarding Switzerland, see SCHINDLER, supra note 6, at 379-83 (discussing the reluctance of Swiss courts to get involved in primarily political decisions and advocating for a judicial review of variable intensity).

116. Regarding the United States, see, for example, Zivotofsky ex rel. Zivotofsky v. Kerry, 576 U.S. 1, 22 (2015) ("[T] he Court has mentioned both of the political branches in discussing international recognition, but it has done so primarily in affirming that the Judiciary is not responsible for recognizing foreign nations.”). 
relate, first and foremost, to the - total or partial, actual or perceivedlack of justiciability of these decisions, ${ }^{117}$ rather than to judicial deference to administrative interpretation of statutes. The distinction between lack of justiciability and judicial deference is, however, not clear-cut_indeed, the concepts may partially overlap. Additionally, as explained above, ${ }^{118}$ the interpretation of a statute often raises policy issues which are sometimes of great political significance.

The political question doctrine in the United States or a similar fundamental limit to judicial review in another country should not play an important role, if any, in statutory interpretation cases involving agencies or other administrative bodies. It would be paradoxical to consider that decisions made by agencies are so political in nature that they exclude or strongly limit judicial review. This argument may be valid for decisions, such as planning decisions, taken by the legislature, the head of state or government, the government as a whole, or a department or ministry, but much less for an agency or, more generally, the bureaucracy. ${ }^{119}$

Nevertheless, agencies or similar bodies may decide on important matters which are politically significant. They typically enjoy a high level of discretion when adopting appropriate measures regarding matters upon which they decide. As far as statutory interpretation is concerned, one may wonder whether they should have political discretion to interpret the statute that they administer. This type of discretion would not be based on the particular expertise that, for instance, an agency has, but solely or essentially on the political dimension or character of the decisions to be made. A note of caution is required here. ${ }^{120}$ When decisions have such a dimension, the risk of political interference is probably, ceteris paribus, higher. An agency or another body-especially if it is not independent within the executive branch-may be inclined to give great weight to the government's current concerns or preferences when it politically matters, ${ }^{121}$ and, to

117. From a comparative perspective, see DALY, supra note 16, at 267-86. Regarding Australia, see Kingham, supra note 95, at 53-68. Regarding Germany, see BoscH, supra note 62, at 81. Regarding the United Kingdom, see Dominic McGoldrick, The Boundaries of Justiciability, 59 INT'L \& COMP. L.Q. 981, 1018 (2010) (concluding, however, that "[t]he modern jurisprudential trend in relation to acts and decisions of the UK executive is to prefer an analysis of issues by reference to relative institutional competence or variable degrees of deference or weight rather than to non-justiciability."). Regarding the United States, see Rucho, 139 S. Ct. at 2506-08.

118. See supra Part IV.A.2.

119. Regarding Germany, see Bosch, supra note 62, at 81, 386; Schmidt-Aßmann, supra note 60, I 197.

120. Regarding Germany, see Bosch, supra note 62, at 80; Schmidt-Aßmann, supra note 60, ๆ 197.

121. Regarding the United States, see Motor Vehicle Mfrs. Ass'n v. State Farm Mut. Auto. Ins. Co., 463 U.S. 29, 59 (1983) (Rehnquist, J., concurring in part and dissenting in part) ("The agency's changed view of the standard seems to be related to the election of a new President of a different political party. It is readily apparent that 
a certain extent, neglect what the legislature had previously decided on the basis of other concerns or preferences. Accordingly, judicial checks may actually protect the legislature. ${ }^{122}$ Any substantial judicial deference in this context would, at the very least, be questionable and could prove detrimental to the legislature. Political discretion may be granted by the legislature, but it cannot be created by the executive or the judiciary branches with the purpose of escaping legislative limits and obligations.

Within the applicable international, constitutional, and other limits, discretion may of course be explicitly granted by the legislature or by the people to an agency or another administrative body in view of the political dimension of the decisions to be made on the basis of the relevant statute. ${ }^{123}$ In such a case, courts should interpret, without any particular deference, the constitutional provision or statute granting such discretion. In doing so, they can determine the scope, level, and limits of discretion and can thus ensure that provisions are not interpreted outside the bounds of the relevant statute.

\section{B. Optimal Allocation of Resources}

Judicial deference to administrative decisions may be understood as a way for a country to optimally allocate resources, ${ }^{124}$ which are usually limited, especially in small countries. Administrative officials

the responsible members of one administration may consider public resistance and uncertainties to be more important than do their counterparts in a previous administration. A change in administration brought about by the people casting their votes is a perfectly reasonable basis for an executive agency's reappraisal of the costs and benefits of its programs and regulations. As long as the agency remains within the bounds established by Congress, it is entitled to assess administrative records and evaluate priorities in light of the philosophy of the administration." (footnote omitted)).

122. Regarding the strong potential of misalignment in the United States between the interests and objectives of Congress and those of agencies, which are primarily accountable to the President, see Dolehide, supra note 102, at 1394-99. If "the American system involves significant principal-agent problems between Congress and executive agencies, as well as between the President and the agencies," $i d$. at 1398, political accountability may indeed be unclear, and the related rationale for deference rather weak. But see MARK TUSHNET, TAKING BACK THE CONSTITUTION: ACTIVIST JUDGES AND THE NEXT AGE OF AMERICAN LAW 161-63 (2020) (not distinguishing between agencies headed by Democrats or Republicans, on the one hand, and courts with a majority of judges appointed by Democrats or Republicans, on the other hand). One may, however, take into account the independence of the judiciary and, in this regard, make ceteris paribus a difference between agencies belonging to the executive branch and courts.

123. Regarding Germany, see BosCH, supra note 62 , at 82, 109-14.

124. Regarding Germany, see Hoffmann-Riem, supra note 4, at 750-51. Regarding the United States, see Statement of Emily Hammond, supra note 86, at 72 ("The deference regimes are best understood as part of a larger constitutional framework, within which courts attempt to optimize their reviewing role, the legislature's desires as expressed in the statutory mandate, and the executive branch's policymaking discretion."). 
and staff have specific expertise, and even though judges control administrative decisions, they do not second-guess the reasonable interpretation of statutes. ${ }^{125}$ Judges often lack the expertise for a full assessment of the motives behind these decisions, and the systematic appointment of court experts in all cases is costly and causes undue delay.

Moreover, judges may ultimately adopt a deferential attitude towards court experts appointed in a case: one form of deference would be replaced by another. Why would it be more legitimate for the courts to interpret the language of a statute by relying on private experts they appoint rather than on the supposedly expert administrative body? Isn't the latter at least tied into the administrative structure subject, as a whole, to democratic control by the government and the legislature? In other words, it is not clear whether the second typedeference to private persons acting as experts-is preferable to the first-deference to agencies or other bodies acting in the public interest. ${ }^{126}$ A general judicial preference for expert analysis over agency analysis would raise important institutional concerns and prima facie would not be justifiable. ${ }^{127}$ A case-by-case approach would be more appropriate in this context.

The optimal allocation of resources, which is considered here, is essentially linked to agencies' or other bodies' specific expertise. In this respect, it does not correspond to an additional independent reason supporting judicial deference to administrative statutory interpretation and derives from the main argument relating to agencies' or other administrative bodies' expertise and experience made previously. ${ }^{128}$

\section{Judicial Honesty, Transparency, and Humility}

By stating that they defer, to a certain extent, to statutory interpretation by administrative bodies, courts simply declare what they actually do and are able to do. Courts neither possess the same legitimacy as administrative bodies, nor do they possess the same level of non-legal expertise, and they do not hide this reality. In this

125. For a rather radical approach on this issue, see LEWANS, supra note 16, at 223 ("[J]udges should hone methods for scrutinizing administrative decisions, which focus on whether an administrative decision is transparent, intelligible and justifiable, instead of attempting to ascertain whether its substance matches their interpretation of the law all things considered.").

126. From a broader perspective, see, regarding the United States, ESKRIDGE, supra note 99, at 277 ("If statutory interpretation is usually a governance moment with consequences for public policy, then agency implementation, experience, and experiments offer lessons and insights that judges cannot easily find anywhere else.").

127. Regarding Italy, see JORDÃO, supra note 16, at 215 .

128. See supra Part IV.A.1. 
perspective, judicial deference can be regarded as an act of judicial honesty, transparency, and even humility. ${ }^{129}$ Courts avoid the hypocrisy of saying that they do not defer in any way, while they know or should know that this does not reflect reality.

Once again, this approach is most often intrinsically related to agencies' or other bodies' specific expertise. Judges know that they are not able to fully correct the asymmetry of non-legal expertise when they review all or part of administrative decisions. Their honesty and transparency in this respect also send a signal to the legislature, which can adopt corrective measures or, expressly or tacitly, approve such a limit of judicial review. This could lead to the creation of specialized courts or to a budget increase of the judiciary, allowing for the recruitment of staff specialized in non-legal matters or the frequent appointment of court experts. ${ }^{130}$ In short, transparency may open appropriate-and possibly fruitful-inter-branch dialogue.

The European Commission is not supposed to benefit from any judicial deference, for instance, with respect to legal questions in competition law cases, except when it applies its own soft law. ${ }^{131}$ Hence, Union courts assess the appropriateness of interpretations of vague legal notions made by the Commission or other bodies in the process of law enforcement. ${ }^{132} \mathrm{~A}$ tendency towards strengthening the intensity of judicial review can henceforth be observed. ${ }^{133}$ Still, "the Commission's record in persuading the EU Courts to accept the theories it puts forward is significant." 134 Therefore, theory may not completely match reality. ${ }^{135}$ Of course, a note of caution is probably justified here, as EU courts may be persuaded without exercising

129. See McMillan, supra note 97, at 27, 33 ("In a basic sense, a practice of deference could be viewed as simply an exercise in common sense and professionalism. It involves recognition that one's skill set may be limited and would benefit from the practical wisdom of others.").

130. See JORDÃO, supra note 16, at 201-17, 570.

131. See, e.g., Maciej Bernatt, Transatlantic Perspective on Judicial Deference in Administrative Law, 22 Colum. J. EuR. L. 275, 311-14 (2016); Heike Schweitzer, Judicial Review in EU Competition Law, in HANDBOOK ON EUROPEAN COMPETITION LAW: ENFORCEMENT AND PROCEDURE 491, 497-98, 531-33, 537-38 (Ioannis Lianos \& Damien Geradin eds., 2013).

132. See, e.g., Mariolina Eliantonio, Deference to the Administration in Judicial Review: The European Union, in DEFERENCE TO THE ADMINISTRATION IN JUDICIAL REvIEW, supra note 16, at 165, 171; Mariusz Baran, The Scope of EU Courts' Jurisdiction and Review of Administrative Decisions: The Problem of Intensity Control of Legality, in RESEARCH HANDBOOK ON EU AdMINISTRATIVE LAW 292, 307 (Carol Harlow, Päivi Leino \& Giacinto della Cananea eds., 2017).

133. See, for instance, Case T-679/14, Teva UK v. Comm'n, 2018 EUR-Lex ECLI:EU:T:2018:919 paras. 165-244 (Dec. 12, 2018), regarding the definition of the "concept of a restriction of competition by object."

134. Bernatt, supra note 131 , at 323.

135. On this issue, see, for example, Damien Gerard, Breaking the EU Antitrust Enforcement Deadlock: Re-Empowering the Courts?, 36 EUR. L. REV. 457, 470-71 (2011). 
deference. That being said, following a given economic theory may have an influence on the interpretation of competition law. ${ }^{\mathbf{1 3 6}}$

\section{Other Considerations}

Some areas are very complex, and an administrative body may be better equipped than a court-in terms of personal resources for instance - to amass the relevant information and take account of all stakeholder views before making a decision. ${ }^{137}$ Complexity, as a practical justification for subsequent judicial deference, is, however, tied to expertise. ${ }^{138}$ One may regard complexity as an independent justification, but this would, first and foremost, relate to fact-finding or to the adoption of regulations, ${ }^{139}$ bylaws, or guidelines, and less to the interpretation of ambiguous or unclear statutes, especially in adjudications. Legal interpretation, including of complex norms, is one of the courts' core competencies.

Along the same lines, participation of interested parties in the administrative decision-making process may give rise to a particular procedural legitimacy, ${ }^{\mathbf{1 4 0}}$ which courts would then have to respect. Here again, one may wonder whether this potential justification for judicial deference really applies to the interpretation of statutes. An affirmative answer should not be excluded, but would most probably flow from the additional knowledge and expertise gained as a result of the decision-making process.

Finally, when they believe that judicial deference to administrative decisions may be justified in some cases, judges should, in principle, address this issue and try to set criteria in this respect in order to avoid or mitigate risks of arbitrariness, and to open a transparent debate in this respect. ${ }^{141}$ In Brazil, for instance, a

136. See, e.g., Schweitzer, supra note 131, at 507 ("In competition law-factintensive by nature and characterized by broad and open legal terms meant to enable the courts to translate economic theory into law-the lines between the evaluation of the facts, the interpretation of the law and an assessment whether the facts adduced suffice to substantiate a legal claim can easily blur. The frequently broad legal concepts gain their full meaning in interaction with economic theory and in their case-by-case application to a given set of situation-specific facts.").

137. On this issue, see DALY, supra note 16, at 89-110.

138. See id. at 89-90, 95, 99.

139. See id. at 252-53 ("Expertise might very well be relevant to the resolution of major questions of policy, for example, whether genetically modified foods should be permitted or not. Complexity, similarly, might be relevant: the question of how to regulate tobacco products and how any regulation would interact with existing regulatory regimes, is a polycentric question which might call for resolution by a procedurally flexible expert body.").

140. See id. at 114-31.

141. Regarding New Zealand, see Bree Huntley, Judicial Review of Administrative Interpretations: Lessons for New Zealand from the United States?, 26 N.Z. U. L. REV. 791, 817-18 (2015) ("One reason that more open engagement with the issues governing 
consistent case law on the interaction between independent agencies and courts is missing, ${ }^{\mathbf{1 4 2}}$ even though higher federal courts sometimes tend to show deference to these agencies. ${ }^{143}$ Brazilian courts have not, for instance, developed a doctrine of judicial deference similar to the Chevron deference in the United States. The same can be said about South Korea, where judicial deference can actually be perceived in some administrative cases. ${ }^{144}$ Finally, in China, judicial deference to administrative decisions exists, but courts have not yet adopted consistent methodologies in this regard. ${ }^{145}$

allocation of interpretive authority would be preferable is it might be expected to lead to better decision making. Judges forced to articulate why they are deferring, or not deferring, to an administrative interpretation must evaluate the arguments for and against deference, rather than relying on their instinctive conclusions. As well, such articulation can serve as a guide to other judges, so that over time a broad consensus emerges as to the relevance of various factors.").

142. See Eduardo Jordão, Globalization and Convergence in Judicial Review: What Can We Learn from the Case of Brazil?, 69 REVISTA DE DiREITO ADMINISTRATIVo E Constitucional [ADMin. \& Const. L. REV.] 23, 30 (2017) ("[T]he adoption of Chevron orientation is still unclear. The doctrine has seduced the academia and many articles have been written on the topic, most of which urging Brazilian courts to adopt a similar doctrine. But empirical studies have shown that actual judicial deference to administrative agencies' decisions is still rare."); see also Eduardo Jordão \& Renato Toledo Cabral Jr., A teoria da deferência e a prática judicial: um estudo empírico sobre o controle do TJRJ à AGENERSA [Theory of Deference and Judicial Practice: An Empirical Study of Judicial Review of AGENERSA (Independent Regulatory Commission of Energy and Basic Sanitation of the State of Rio de Janeiro) by TJRJ (Court of Justice of the State of Rio de Janeiro)], 4 REVISTA DE ESTUDOS INSTITUCIONAIS [REV. OF INSTITUTIONAL STUD.] 537, 565-66 (2018).

143. See Mariana Mota Prado, Introdução [Introduction], in O JUDICIÁRIO E O ESTADO REGULADOR BRASILEIRO [COURTS AND THE BRAZILIAN REGULATORY STATE] 7, 11 (Mariana Mota Prado ed., 2016); Juliano Souza de Albuquerque Maranhão, A revisão judicial de decisões de agências regulatórias: jurisdição exclusiva? [Judicial Review of Decisions of Regulatory Agencies: Exclusive Jurisdiction?], in COURTS AND THE Brazilian Regulatory State, supra note 143, at 25, 25 \& 29; Paulo Furquim de Azevedo, Revisão judicial de decisões antitruste: incentivos para acordos? [Judicial Review of Antitrust Decisions: Incentives for Settlements?], in COURTS AND THE BRAZILIAN REgulatory State, supra note 143, at 81, 89 \& 99; Patrícia Sampaio \& Ricardo Morishita Wada, A regulação e o Judiciário: o caso do setor de eletricidade [Regulation and the Judiciary: The Case of the Electricity Sector], in COURTS AND THE BRAZILIAN REgulatory STATE, supra note 143, at 135, 149; Alexandre D. Faraco, Caio Mario da Silva Pereira Neto \& Diogo R. Coutinho, A judicialização de políticas regulatórias de telecomunicações no Brasil [Judicial Review of Telecommunications Policies in Brazil], in COURTS AND THE BRAZILIAN REGULATORY STATE, supra note 143, at 161, 176-78.

144. See Dong Won Kim, Finding a Model of Judicial Review for Administration: Implications from the Chevron Case for Separation of Powers in South Korea, 21 INT'L REV. PUB. ADMIN. 147, 153-60 (2016).

145. Qinwei Gao, Deference to the Administration in Judicial Review in China, in DEFERENCE TO THE ADMINISTRATION IN JUDICIAL REVIEW, supra note 16, at 105, 128-29 ("[I]t is necessary for the courts to unify the standard of judicial review. In the course of judicial review, the Chinese courts will have more experience to establish a reasonable spectrum of scrutiny: in the field of policy making, the courts respect the margin of appreciation of administrative organs; in the field of expertise, such as food safety and risk regulation, the courts also loose the intensity of review; stricter scrutiny could be 


\section{The CASE Against Judicial Deference}

The separation of powers principle and the concept of checks and balances (subpart A), the rule of law or the not-too-distant-though not synonymous-notion of "État de droit" (subpart B), the constitutional role of the judiciary (subpart C), as well as procedural safeguards (subpart D) usually support the case against a general and broad judicial deference to administrative statutory interpretation. Agency independence (subpart E), when it exists, and the risk of wrong incentives, as well as other considerations (subpart F), may also support the case against judicial deference.

\section{A. Separation of Powers and Checks and Balances}

The separation of powers principle and the concept of checks and balances are invoked to oppose judicial deference to administrative statutory interpretation. ${ }^{\mathbf{1 4 6}}$ Without full effective control of the judiciary over administrative decisions, checks needed for the executive would be insufficient, and the separation of powers principle would be disregarded. However, one has to be clear about how the separation of powers is affected by such deference. In the United States, it is not so much "a judicially orchestrated shift of power from Congress to the Executive Branch,"147 but rather an eventual shift of power to this branch from the judiciary with the supposed assent of the Congress. ${ }^{148}$

This approach can perhaps be followed when general judicial deference is considered, including with respect to decisions of deep social, political, or economic significance. ${ }^{149}$ However, some deference,

applied when administrative organs make a decision on punitive penalty or the deprivation of freedom or property rights of citizens.").

146. Regarding the United Kingdom, see, for example, Trevor R. S. Allan, Human Rights and Judicial Review: A Critique of "Due Deference," 65 CAMBRIDGE L.J. 671, 675, 677-82, 695 (2006). Regarding the United States, see, for example, Cynthia R. Farina, Statutory Interpretation and the Balance of Power in the Administrative State, 89 Colum. L. REv. 452, 456, 516-28 (1989); Jack. M. Beermann, End the Failed Chevron Experiment Now: How Chevron Has Failed and Why It Can and Should Be Overruled, 42 CONN. L. REV. 779, 836--37 (2010); Statement of Jonathan Turley, supra note 58, at 15. For a literature review, see Christopher J. Walker, Attacking Auer and Chevron Deference: A Literature Review, 16 GEO. J. L. \& PUB. POL'Y 103, 110-20 (2018).

147. Kavanaugh, supra note 106, at 2150 (referring to the Chevron case).

148. Gutierrez-Brizuela v. Lynch, 834 F.3d 1142, 1152 (10th Cir. 2016) (Gorsuch, J., concurring). See also Sunstein, supra note 60, at 1616 n.12.

149. Regarding the United States, see FDA v. Brown \& Williamson Tobacco Corp., 529 U.S. 120, 160 (2000); King v. Burwell, 576 U.S. 473, 484-87 (2015). The absence of deference on a question of deep "economic and political significance" which is central to the statutory scheme at stake is an important exception to the Chevron doctrine. It remains to be seen whether the exception will overshadow the rule since it is difficult to delineate the limits to the exception. 
based on several criteria, does not shake the foundation of the separation of powers, especially when administrative decisions are still reviewed by courts to an important extent. ${ }^{150}$ Montesquieu, for instance, did not insist on the process of interpreting laws: the judiciary almost mechanically applied them to concrete cases. ${ }^{151}$

Paradoxically, the separation of powers principle and the concept of checks and balances are sometimes invoked to support judicial deference to administrative statutory interpretation, as we have seen. ${ }^{152}$ A too-extensive judicial review of administrative decisions would give too much power to the judiciary and would create an imbalance in favor of the latter. This goes to show that considerations based on the separation of powers principle, the concept of checks and balances, or even a theory of democracy are, if not irrelevant, ambivalent. ${ }^{153}$

\section{B. Rule of Law and "État de droit"}

The rule of law and the related concept of "État de droit""Rechtsstaat" in German-are also referred to by courts, judges, and scholars widely or totally opposed to judicial deference to

150. From a comparative perspective, see JORDÃO, supra note 16, at 536-37. Regarding the United States, see Sunstein, supra note 60, at 1678 ("But if Congress wants agencies to interpret ambiguous statutes, it can grant them that authority [so long as that, and no more, is what it is granting]. If Congress wants to deny agencies interpretive authority and require an independent judicial role, it can do that as well. Constitutional objections to the Chevron framework are unconvincing." (footnote omitted)); Gillian E. Metzger, The Supreme Court, 2016 Term - Foreword: 1930s Redux: The Administrative State Under Siege, 131 HARV. L. REV. 1, 93 (2017) ("Unless such delegations are unconstitutional, the constitutional separation of powers system requires that the courts honor congressional policy choices. And honoring congressional choices to delegate means deferring to agency judgments within the sphere of the agency's constitutionally delegated authority." (footnote omitted)).

151. Montesquieu, The Spirit of The LAWs 160 (Anne M. Cohler, Basia Carolyn Miller \& Harold Samuel Stone eds. \& trans., 1989) (1748) (“Among the three powers . . ., that of judging is in some fashion, null."); see Charles Eisenmann, L'Esprit des Lois et la Séparation des Pouvoirs [The Spirit of the Laws and the Separation of Powers] (1933), reprinted in ÉCRITS DE THÉORIE DU DROIT, DE DROIT CONSTITUTIONNEL ET D'IDÉES POLITIQUES [WRITINGS IN THEORY OF LAW, CONSTITUTIONAL LAW AND POLITICAL IDEAS] 565, 575 (Charles Leben ed., 2002); see also Zeev Segal, Judicial Activism Vis-à-Vis Judicial Restraint: An Israeli Viewpoint, 47 TULSA L. REV. 319, 321 (2011).

152. See supra Part IV.A.3.

153. See Zhu, supra note 18 , at 8, 16; Tolley, supra note 84, at 432-34; see also Paul Tucker, Unelected Power: The Quest For Legitimacy IN Central Banking AND THE REGULATORY STATE 339-40 (2018) ("It is not clear that simply dropping the Chevron doctrine would help live up to the values of constitutional democracy. If the courts did not defer to agency interpretation . . ., they, rather than the agency, would become the de facto legislators, as occurred in competition policy: hardly an advance in terms of democratic legitimacy."); Antonin Scalia, Judicial Deference to Administrative Interpretations of Law, 1989 DUKE L.J. 511, 514-16. 
administrative statutory interpretation. ${ }^{154}$ In France, the "État de droit," the role of courts - ultimately of the Court of Cassation and the Council of State-as well as procedural safeguards are considered to prohibit any judicial deference to independent administrative authorities' statutory interpretation. ${ }^{155}$ In Finland, the principles of legality and effective judicial protection, the right to a fair trial, and other fundamental rights are usually interpreted as preventing this type of deference. ${ }^{156}$ Once a statute is enacted in Israel, its interpretation by agencies does not, as a rule, receive judicial deference since the view from the bench is that the courts' role is to interpret the law. ${ }^{157}$ A recent decision of the Supreme Court appears, however, to lean toward a Chevron-type doctrine, ${ }^{158}$ though its actual meaning is debated. ${ }^{159}$ Moreover, it is very difficult for now to foresee whether this decision will remain isolated or establish an important precedent. ${ }^{\mathbf{1 6 0}}$

Both the rule of law and the "État de droit" imply, among other things, public authorities' subjection to the applicable laws and the independence of the judiciary. These notions are, however, imprecise

154. Regarding the United States, see, for example, Ronald A. Cass, Vive La Deference?: Rethinking the Balance Between Administrative and Judicial Discretion, 83 GEO. WASH. L. REV. 1294, 1322-23, 1328-29 (2015).

155. See, e.g., Jean-Louis Autin, Autorités administratives indépendantes, démocratie et État de droit [Independent Administrative Authorities, Democracy and Rule of Law], 93 DROIT ET SOCIÉTÉ [L. \& SOC'Y] 285, 293-94 ("État de droit" is translated here as "Rule of Law," as there is no exact equivalent in English; one should bear in mind that this translation is imprecise); JORDÃO, supra note 16, at 41-45, 148-49; see also Bertrand du Marais, Les règles juridiques matérielles applicables aux autorités indépendantes [Material Legal Rules Applicable to Independent Authorities], in LE MODÈLE DES AUTORITÉS DE RÉGULATION INDÉPENDANTES EN FRANCE ET EN ALLEMAGNE [The Model of INDEPENDENT REgulation Authorities IN FRANCE AND IN GERMANY] 231, 249-51 (Gérard Marcou \& Johannes Masing eds., 2011). For a general view on countries with a civil law tradition, see Craig, supra note 14, at 401 ("The conceptual premise of US, Canadian law, and to a lesser extent UK law, that some interpretive autonomy over legal issues should be accorded to agencies, whether on grounds of delegation, expertise or accountability, would in general not be accepted by those [EU Member States] in the civil law tradition."). As we shall see, some civil law countries like Germany, Italy and Switzerland, grant administrative bodies some statutory interpretation autonomy.

156. See Olli Mäenpää, Deference to the Administration in Judicial Review in Finland, in DEFERENCE TO THE ADMINISTRATION IN JUDICIAL REVIEW, supra note 16, at 181, 188-89, 199-200.

157. See, e.g., HCJ 3648/97 Stamka v. Minister of the Interior, 53(2) PD 728 paras. 8-11 (1999) (Isr.). On the doctrine of reasonableness in Israel, see, for example, Michael Asimow \& Yoav Dotan, Open and Closed Judicial Review of Agency Action: The Conflicting U.S. and Israeli Approaches, 64 AM. J. CoMP. L. 521, 549-50 (2016).

158. CA 7488/16 Seligman v. Phoenix Insurance Company Ltd. paras. 33-34 (a further hearing of the case by an extended panel has been ordered, FH 4960/18, and is currently pending; last checked Feb. 21, 2021). On this decision, see Margit Cohn, Judicial Deference to the Administration in Israel, in DEFERENCE TO THE ADMINISTRATION IN JUDICIAL REVIEW, supra note 16, at 231, 265-66.

159. See Cohn, supra note 158 , at 266 .

160. See id. at 267. 
and elusive. They would likely be misread if interpreted so as to prevent any form of judicial deference in any statutory interpretation cases. ${ }^{161}$ In New Zealand nevertheless, the Court of Appeal stated that it is "fundamental and constitutionally important" to the preservation of the rule of law that courts have the last word on questions of law. ${ }^{\mathbf{1 6 2}}$ Accordingly, courts do not defer to statute interpretation by agencies. Some scholars are, however, in favor of a judicial deference doctrine similar to the one existing in Canada; they consider that there would be no legal obstacle to having this kind of deference in New Zealand as well. ${ }^{163}$

Extensive self-restraint on the part of the courts could become particularly problematic if and when it would make effective judicial control over the executive branch difficult or, a fortiori, illusory. Along these lines, the rule of law may limit or forbid judicial deference "on general questions of law of central importance to the legal system as a whole," 164 providing that these terms do not create a catch-all instrument for courts. Besides, even if its nature differs from judicial review, parliamentary control over agencies is rather weak in many democracies for reasons that vary from one country to the next.

In short, an unchecked executive branch endangers or even collides with the rule of law and the "État de droit." Limited judicial deference in statutory interpretation cases, however, does not reach

161. Regarding countries with a Common Law tradition, see Hanna Wilberg \& Mark Elliott, Deference on Questions of Law: A Survey of Taggart's Contribution and Themes in the Wider Literature, in THE ScOPE AND INTENSITY OF SUBSTANTIVE REVIEW, supra note 89, at 197, 214 ("[N]one of the major common-law systems actually treats every question of statutory interpretation as a matter that must inevitably attract correctness review. It follows that the real fault-line in the debate relates not to the question whether deference is ever appropriate. Rather, the principal site of disagreement is found in relation to questions pertaining to the circumstances in which deference is appropriate and the means by which deference, when it is appropriate, should be delivered.").

162. Wool Board Disestablishment Co. Ltd. v. Saxmere Co. Ltd. [2010] NZCA 513, [2011] 2 NZLR 442 at [116-17, 224] (N.Z.); see, e.g., Aronson, supra note 91, at 257-59, 260; Huntley, supra note 141, at 793-97; see also Hanna Wilberg, Deference on Relevance and Purpose? Wrestling with the Law/Discretion Divide, in THE SCOPE AND INTENSITY OF SubSTANTIVE REVIEW, supra note 89, at 263.

163. See Wilberg \& Elliott, supra note 161, at 209; Michael Taggart, The Contribution of Lord Cooke to Scope of Review Doctrine in Administrative Law: A Comparative Common Law Perspective, in The STRUGGLe FOR SimPlicity IN THE LAW: EssaYs IN HONOUR OF LORD COOKE OF THORNDON 189, 215-19 (Paul Rishworth ed., 1997); see also Huntley, supra note 141, at 817-18.

164. See the case law of the Supreme Court of Canada, most recently Canada (Minister of Citizenship and Immigration) v. Vavilov, 2019 S.C.C. 65, paras. 58-62. But see Paul Daly, Vavilov Hits the Road, ADMIN. L. MATTERS (Feb. 4, 2020), https://www.administrativelawmatters.com/blog/2020/02/04/vavilov-hits-the-road/ [https://perma.cc/MK9V-55QX] (archived Sep. 29, 2020) ("The category most apt to be expanded after Vavilov is surely the 'questions of central importance to the legal system' category. But the narrow rule of law basis for the correctness categories does not provide a solid foundation for such arguments.”). 
these dangerous limits. ${ }^{165}$ The historical and legal context prevailing in a country may of course lead to another conclusion. Accordingly, the rule of law and the "État de droit" must be contextualized.

\section{Constitutional Role of the Judiciary}

Many constitutions define the role or the roles of the judiciary in general terms. Very few of them expressly mention that the judiciary interprets the law without limits. Thus, constitutions are usually vague as far as statute interpretation is concerned. They do not address the question of judicial deference regarding decisions made by other branches.

In some countries, such as Mexico, courts consider that the constitution ${ }^{166}$ assigns them the task to interpret statutes and, consequently, that they cannot defer to agencies in this respect. In Argentina, ${ }^{167}$ federal courts see one of their roles as interpreting statutes in federal or constitutional controversies and, thus, would not accept to defer to agencies in this regard. In other countries, such as Belgium and Spain, no debate on this issue seems to exist.

In South Africa, the constitutional provision guaranteeing administrative justice, as well as the legacy of apartheid, may explain, at least partly, why South African courts are reluctant to defer to statute interpretation by agencies. ${ }^{168}$ Section 33 ("Just Administrative Action") of the South African Constitution ${ }^{\mathbf{1 6 9}}$ notably provides that "[e]veryone has the right to administrative action that is lawful, reasonable and procedurally fair" (par. 1) and that national legislation "must provide for the review of administrative action by a court or, where appropriate, an independent and impartial tribunal" (par. 3/a). In this country, there is indeed no judicial deference to administrators

165. Regarding Canada, see David Dyzenhaus, Dignity in Administrative Law: Judicial Deference in a Culture of Justification, 17 REv. ConsT. STUD. 87, 107-14 (2012), focusing on the idea of "deference as respect". Regarding Canada and the United States, see Daly, supra note 14, at 720 and, from a broader perspective, DALY, supra note 16, at 291-93. Regarding the United States, see Eskridge \& Baer, supra note 78, at 1169-71. From a general perspective, see Paul Craig, Judicial Review and Judicial Deference, in Controlling EU Agencies: The Rule of LAW in a Multi-JURISDictional Legal ORDER 98, 99-100, 102-03 (Miroslava Scholten \& Alex Brenninkmeijer eds., 2020).

166. Constitución Política de los Estados Unidos Mexicanos, CP, Diario Oficial de la Federación [DOF] 05-02-1917, últimas reformas DOF 10-02-2014 art. 103; see also Ley Orgánica del Tribunal Federal de Justicia Administrativa [Administrative Justice Federal Tribunal Organic Act] [LOTFJA] art. 3, Diario Oficial de la Federación [DOF] 18-07-2016 (Mex.).

167. See Pedro Aberastury, Deference to the Administration in Judicial Review in Argentina, in DEFERENCE TO THE AdMinistration In JUdiCial REVIEW, supra note 16, at $23,30-36$.

168. See Cora HoeXter, Administrative LaW IN SOUTH AFriCA 147-55, 353-55 (2nd ed. 2012); Tolley, supra note 84, at 430-32, 438 (2003).

169. S. AFr. CONST., $1996 \S 33$. 
when it comes to the interpretation of legislation. ${ }^{170}$ In a few cases, courts have admittedly shown reluctance to interfere with complex decisions taken by administrators with specific expertise, but the deference did not relate to statute interpretation. ${ }^{171}$

In other countries, the constitution is generally regarded as allocating the function of statute interpretation to courts without allowing them to defer, in this regard, to administrative bodies. Australia seems to provide a good illustration in this regard. ${ }^{172} \mathrm{Also}$, given the particular constitutional framework existing in Sweden, with wide powers granted to administrative courts, judicial deference to statute interpretation by agencies does not seem to exist in this country. ${ }^{173}$ In India, the question of judicial deference to statute interpretation by agencies does not seem to arise "since the judiciary inherently believes that the task of adjudicating in all aspects is a judicial function alone." ${ }^{174}$ That said, in the interpretation of tax statutes, the Indian Supreme Court does not admit to the use of deference, but to the use of admissible and significant aid for interpretation:

a uniform and consistent departmental practice arising out of construction placed upon an ambiguous statute by the highest executive officers at or near the time of its enactment and continuing for a long period of time is also an admissible aid to the proper construction of the statute by the court and would not be disregarded except for cogent reasons. ${ }^{\mathbf{1 7 5}}$

170. See Marshall NO v. Commissioner, South African Revenue Service 2009 (6) SA 246 (CC) paras. 3, 9, 10 (S. Afr.) (rejecting the argument that "a unilateral practice of one part of the executive arm of government" should play any role in determining the meaning of a statutory provision relating to VAT and holding that the meaning of such a provision has to be interpreted objectively and independently by courts); see also HOEXTER, supra note 168, at 282-90 (discussing the notion of "error of law" which is the ground of review that specifically addresses wrong or mistaken statutory interpretation by administrators).

171. See, e.g., High Court of South Africa May 9, 2005, Joubert v. National Commissioner for the South African Police Service (6543/2004) [2005] ZAGPHC 238 (decision of medical board); Cora Hoexter, A Rainbow of One Colour? Judicial Review on Substantive Grounds in South African Law, in THE SCOPE AND INTENSITY OF SUBSTANTIVE REVIEW, supra note 89, at 163, 170-71 \& 192.

172. See, e.g., Kingham, supra note 95, at 61-62; Cane, supra note 91, at 221-33, 237-38; Peter CANe, Controlling Administrative Power: AN Historical COMPARISON 217-18, 230, 235 (2016); Freckelton, supra note 94, at 64-66; Barnes, supra note 40, at 133. But see Gageler, supra note 94, at 154-56.

173. See, e.g., Henrik Wenander, Full Judicial Review or Administration Discretion? A Swedish Perspective on Deference to the Administration, in DEFERENCE TO THE ADMINISTRATION IN JUDICIAL REVIEW, supra note 16, at 405, 407-11, 413-14.

174. Roopashi Khatri, Administrative Agency and Statutory Interpretation: A Comparative Analysis, 1.1 CoMP. ConsT. L \& ADMIN. L.Q. 32, 41 (2013).

175. Jagdamba Indus. v. State of Madhya Pradesh, (1988) 69 STC 1 para. 14 (SC) (India) (holding that the statute at issue was silent on the matter at hand). 
The Court of Justice of the European Union ensures "that in the interpretation and application of the Treaties the law is observed." 176 This "constitutional" mandate means that questions of law arising from the interpretation of Treaty provisions such as Articles 101 and 102 of the Treaty on the Functioning of the European Union are subject to full and comprehensive judicial review. ${ }^{177}$

In sum, the constitutional role of the judiciary is, to a certain extent, a question of interpretation. Courts themselves have a say in this respect. Accordingly, they define the outlines of their interpretive power. In Hong Kong, for instance, courts have not developed a doctrine of deference to agencies' interpretation of statutes. ${ }^{178}$ A key reason may be that Hong Kong courts are of British tradition, and since the British courts have not developed a doctrine akin to Chevron deference, courts in Hong Kong have been firmly of the view that legislative interpretation is a question of law for them to decide. This assessment is also valid for Singapore, ${ }^{179}$ even though various arguments are brought forward in favor of a deference doctrine. ${ }^{180}$

In most countries, then, one cannot say that the constitutional role of the judiciary clearly prohibits judicial deference to administrative statutory interpretation. The way the judiciary itself interprets its constitutional or institutional role may go in this direction, but it is a peculiar form of judicial self-restraint (i.e., a selfimposed restraint on the ability to defer).

\section{Procedural Safeguards}

International, constitutional, statutory, or other procedural safeguards often require courts to fully review the merits of each case by assessing all relevant facts in addition to the correct interpretation of the law and its application to the facts. Case law from the European Court of Human Rights based on the first paragraph of Article 6 of the ECHR lays down such a rule. ${ }^{181}$ Article 47 of the Charter of

176. Treaty on the European Union, Feb. 7, 1992, 1992 O.J. (C 326/13) art. 19(1).

177. Bernatt, supra note 131, at 311-12; Schweitzer, supra note 131, at 498.

178. See Cora Chan, A Principled Approach to Judicial Deference for Hong Kong, in DEFERENCE TO THE ADMINISTRATION IN JUdiCIAL REVIEW, supra note 16, at 203, 224, $227-28$.

179. See Eugene K. B. Tan, 'The Notion of a Subjective or Unfettered Discretion is Contrary to the Rule of Law": Judicial Review of Administrative Action in Singapore, in DEFERENCE TO THE ADMINISTRATION IN JUDICIAL REVIEW, supra note 16, at 379, 397.

180. See id. at 396-400; see also Eugene K. B. Tan, Commercial Judicial Review in Singapore: Strategic or Spontaneous?, 2020 SINGAPORE JOURNAL OF LEGAL STUDIES 448, $472-77$.

181. In case law of the European Court of Human Rights, see, for instance, A. Menarini Diagnostics S.R.L. v. Italy, Eur. Ct. H.R. App. No. 43509/08 paras. 61-67 (Sept. 27, 2011), http://hudoc.echr.coe.int/eng\#\{"fulltext":["in\%20re\%20a.\%20 menarini"],"documentcollectionid2":["GRANDCHAMBER","CHAMBER"],"itemid":["001 
Fundamental Rights of the European Union is interpreted the same way by the Court of Justice of the European Union. ${ }^{182}$

When such a procedural safeguard exists, it gives rise to two sets of fundamental questions which are normally answered by courts. Firstly, what is the actual scope of the safeguard in question? Does it cover all fields of law, including administrative law interpreted and applied by agencies in the first instance? For example, the protection of Article 6 of the ECHR extends to several areas of administrative law, but not to all of them. ${ }^{183}$

Secondly, does a full review really exclude any form of deference, for instance when the interpretation of a statute is intrinsically linked to complex technical, economic, or scientific issues? The European Court of Human Rights does not completely close the door to some kind of judicial deference in such a situation:

In assessing whether, in a given case, the extent of the review carried out by the domestic courts was sufficient, the Court has held that it must have regard to the powers of the judicial body in question and to such factors as: (a) the subjectmatter of the decision appealed against, and in particular, whether or not it concerned a specialised issue requiring professional knowledge or experience and whether it involved the exercise of administrative discretion and, if so, to what extent; (b) the manner in which that decision was arrived at, in particular, the procedural guarantees available in the proceedings before the administrative body; and (c) the content of the dispute, including the desired and actual grounds of appeal. ${ }^{184}$

-106438"]\} [https://perma.cc/SL28-6TSJ] (archived Dec. 10, 2020); see also, e.g., Zhu, supra note 16, at 15; Jean-David Dreyfus, Les autorités de régulation indépendantes au croisement des droits administratif, civil et pénal [Independent Regulation Authorities at the Crossroads of Administrative, Civil and Criminal Law], in THE MODEL OF INDEPENDENT REGULATION AUTHORITIES, supra note 155, at 297, 310-12; Vincent Martenet, Le contrôle judiciaire et la surveillance politique des autorités administratives indépendantes [Judicial Control and Political Oversight of Independent Administrative Authorities], in LES AUTORITÉS ADMINISTRATIVES INDÉPENDANTES [INDEPENDENT ADMINISTRATIVE AUTHORITIES] 183, 191-99 (François Bellanger \& Thierry Tanquerel eds., 2011).

182. See, for instance, Case C-295/12 P, Telefónica SA v. Comm'n, 2014 Eur-Lex CELEX 62012CJ0295, paras. 51-57 (July 10, 2014).

183. On the scope of Article 6 of the European Convention on Human Rights, see European Court of Human Rights, Guide on Article 6 of the European CONVENTION ON HUMAN RIGHTS: Right TO A FAIR TRIAL (CRIMINAL LIMB) paras. 11-52 (Dec. 31, 2020); European Court of Human Rights, Guide on ARTicle 6 of the European CONVENTION ON Human Rights: Right to a FAIR TRIAL (Civil Limb) paras. 1-75 (Aug. 31, 2020).

184. On this issue, see, for example, Martenet, supra note 181, at 196-99; see also, for instance, Ramos Nunes de Carvalho e Sá v. Portugal, Eur. Ct. H.R. App. Nos. $55391 / 13, \quad 57728 / 13 \quad \& \quad 74041 / 13 \quad$ para. 179 (Nov. 6, 2018), http://hudoc.echr.coe.int/eng\#\{"fulltext":["Ramos\%20Nunes\%20de\%20Carvalho\%20e\%2 0Sá\%20v.\%20Portugal"],"documentcollectionid2":["GRANDCHAMBER","CHAMBER"], "itemid":["001-187507"]\} (last visited Dec. 10, 2020) [https://perma.cc/9D6U-6PFK] (archived Dec. 10, 2020); Fazia Ali v. The United Kingdom, App. No. 40378/10, para. 78 
In Italy, for example, the intensity of judicial review over independent authorities' decisions has significantly increased during the last twenty years. ${ }^{185}$ This evolution is notably due to the European Union principle of effective judicial protection, ${ }^{186}$ as well as to Article 6 of the ECHR and Article 113 of the Italian Constitution which provides, in its first paragraph, that "[t]he judicial safeguarding of rights and legitimate interests before the bodies of ordinary or administrative justice is always permitted against acts of the public administration." 187 Since an important decision of the Council of State, ${ }^{188}$ Italy's highest administrative court, the existence of an indefinite legal term in a statute does not alone justify any judicial deference to administrative statutory interpretation. The Italian Supreme Court of Cassation, the highest civil and criminal court, continues however to consider that judicial deference may exist when a court faces complex economic and technical evaluations made by an

(Oct. $\quad 20, \quad$ 2015), http://hudoc.echr.coe.int/eng\#\{"fulltext":["Fazia \%20Ali\%20v.\%20The\%20United\%20Kingdom"],"documentcollectionid2":["GRANDCHA MBER","CHAMBER"],"itemid":["001-158031"]\} (last visited Dec. 10, 2020) [https://perma.cc/K5GX-7E52] (archived Dec. 10, 2020); Tsanova-Gecheva v. Bulgaria, Eur. Ct. H.R. App. No. 43800/12 para. 98 (Sept. 15, 2015), http://hudoc.echr.coe.int/eng\#\{"itemid":["001-157348"]\} (last visited Dec. 10, 2020) [https://perma.cc/3PSW-NWCW] (archived Dec. 10, 2020); Sigma Radio Television Ltd v. Cyprus, App. Nos. 32181/04 \& 35122/05, para. 154 (July 21, 2011), http://hudoc.echr.coe.int/eng\#\{"fulltext":["Sigma\%20Radio\%20Television\%20Ltd\%20v.\% 20Cyprus"],"documentcollectionid2":["GRANDCHAMBER","CHAMBER"],"itemid":["00 1-105766"]\} (last visited Dec. 10, 2020) [https://perma.cc/6EED-SPPL] (archived Dec. 10, 2020).

185. See Vera Parisio, Judicial Review of Italian Independent Authorities Acts: A Short Overview, in The FUture OF Administrative LAW 271, 283-86 (Jean-Bernard Auby ed., 2019); Giacinto della Cananea, Judicial Review of Administrative Action in Italy: Beyond Deference?, in DEFERENCE TO THE ADMINISTRATION IN JUDICIAL REVIEW, supra note 16, at 271, 275-85; JORDÃO, supra note 16, at 165-75.

186. In Italy, see Codice del processo amministrativo [Code of Administrative Trial], Decreto legislativo [Legislative Decree], July 2, 2010, No. 104, art. 1, translated at http://www.unaep.com/download/the-code-of-administrative-trial-codice-del-processoamministrativo-in-lingua-inglese/ (last visited Oct. 9, 2020) [https://perma.cc/L7N7G9S9] (archived Oct. 9, 2020).

187. Art. 133 Constituzione [Cost.] (It.), translated at https://www.senato.it/ documenti/repository/istituzione/costituzione_inglese.pdf (last visited Oct. 9, 2020) [https://perma.cc/4RD8-3G7T] (archived Oct. 9, 2020).

188. Cons. Stato, sez. un., 10 marzo 2003, n. 926/04, 23-26 (It.); ConsigLio DI Stato [Council of State], Ufficio Studi [Research Department], Autorità INDIPENDENTI E SINDACATO GIURISDIZIONALE [INDEPENDENT AUTHORITIES AND JUDICIAL REVIEW] 7-8 (2017). See Vera Parisio, Contrôle juridictionnel des actes des Autorités indépendantes italiennes: un bref aperçu [Judicial Review of Acts of Italian Independent Authorities: A Short Overview], 19 FEDERALISMI.IT - RIVISTA DI DIRITTO PUBBLICO italiano, comparato, europeo [Rev. of Italian, Compar. \& Eur. Pub. L.] 1, 22 (Oct. 10, 2018); JORDÃO, supra note 16, at 174-75. 
independent authority. ${ }^{189}$ For their part, the administrative courts and the Council of State, which can appoint technical experts, ${ }^{\mathbf{1 9 0}}$ notably control whether a given independent authority's statutory interpretation remains within the margin permitted by the indefinite legal term at stake, but are not allowed to substitute their own judgement for that of the authority. ${ }^{191}$ Since complex evaluations made by the authority may influence the interpretation of law and since the appointment of experts is not systematic, some form of judicial deference to administrative statutory interpretation or, at least, some judicial restraint in this respect may de facto still exist in administrative cases in Italy. ${ }^{192}$

In sum, procedural safeguards usually have an impact on the issue of judicial deference to administrative statutory interpretation. In this respect, the exact intensity of judicial review is determined at the last instance by a court, be it supranational, supreme, or constitutional.

\section{E. Independence}

Agencies' independence has already been mentioned as a potential—-though not particularly convincing-argument for judicial deference in statutory interpretation cases. ${ }^{193}$ One could also claim that said independence equates to a lack of political control and reduced accountability in this respect. Judicial deference would lead to a situation where unelected bureaucrats are, to a certain extent, insulated from political accountability and liability as well as from effective judicial review. Appropriate and efficient checks and balances would thus be missing. Such an institutional context is therefore seen

189. Cass., sez. un. 20 gennaio 2014, n. 1013, paras. 4.1-4.3. See, e.g., Parisio, supra note 188, at 22; Marina Tavassi, Judicial Review of Antitrust Decisions: Q\&A, 2 ITALIAN ANTITRUST REV. 144, 160-61 (2015).

190. Art. 19, $63 \S 4,67$ Codice del processo amministrativo [Code of Administrative Trial], Decreto legislativo [Legislative Decree] July 2, 2010, n. 104 (It.).

191. Cons. Stato, sez. un. 26 maggio 2017, nn. 02481/2017, 26-27 (para. 5.1.2); Cons. Stato, sez. un. 24 ottobre 2014, n.. 05274, 6 (para. 4); Cons. Stato, sez. un. 8 agosto 2014 , n. 4228, 4-5 (para. 4.1). See, e.g., Parisio, supra note 188, at 22-23; Mario Filice, Il sindacato giurisdizionale sull'attività delle Autorità indipendenti [Judicial Review Over the Activity of the Independent Authorities], 2015 GIORNALE DI DIRITTO AMMINISTRATIVO [J. ADMIN. L.] 559, 568-69 (2015); Mario Siragusa, Judicial Review of Antitrust Decisions: Q\&A, 2 ITALIAN ANTITRUST REV. 144, 150-51, 157-58 (2015).

192. See Filice, supra note 191, at 569; Roberto Giovagnoli, Judicial Review of Antitrust Decisions: Q\&A, 2 ItAlian ANTITRUST REV. 144, 145-46 (2015); see also CLAUDIO CONTESSA, FORME E METODI DEL SINDACATO GIURISDIZIONALE SUGLI ATTI DELLE AUTORITÀ INDIPENDENTI [FORMS AND METHODS OF JUDICIAL REVIEW OVER ACTS OF THE InDEPENDENT Authorities], Publication of the Council of State 21 (2018).

193. See supra Part IV.A.3. 
as unfavorable to judicial deference to statute interpretation by agencies. ${ }^{194}$

The idea that the intensity of judicial review is inversely proportional to the intensity of political control can be misleading, if not inaccurate. They differ in nature. One should not forget that a debate on judicial deference to statute interpretation by agencies arises both in countries where agencies or other administrative bodies are independent as well as in others where they are not. ${ }^{195}$

Agencies' independence is a double-edged sword with regard to judicial deference in statutory interpretation cases. The lack of political accountability may prevent such a deference, but the reduced risk of political influence in the decision-making process may support it. Accordingly, it seems difficult to give much weight to this element.

Empirical research in a given country - with a view to understand how institutions, their personnel, rules, or procedures actually operate and what effects they have-may indeed show that the lack of political accountability is more problematic than the risk of political influence. Regardless, can courts really rely on empirical studies that are often accompanied by unavoidable assumptions and caveats? Can a principled discussion be based on shaky grounds, as is here the case?

\section{F. Risk of Wrong Incentives and Other Considerations}

In the United States, judicial deference is sometimes said to create incentives for the legislature to vote vague legislation which is then interpreted and applied by agencies whose decisions are not fully reviewed by courts. ${ }^{196}$ This line of reasoning stems from the idea that agencies are more sympathetic to the legislature's views than courts. This may be true when legislation is adopted, but the majority can change and, if agencies do not enjoy strong independence towards the head of state or government, they may be reluctant to apply certain rules enacted by previous parliamentary majorities.

In any event, vague statutory provisions must be interpreted, the lead interpreter being, in this context, either agencies or courts, or a mix of both. Additionally, the legislature is usually entitled to enact

194. Regarding the United States, see FCC v. Fox Television Stations, Inc., 556 U.S. 502, 547-48 (2009) (Breyer, J., dissenting). For a convincing rejection of this approach, see DALY, supra note 16, at 113. Regarding Germany, see generally Bundesverfassungsgericht [BVERFG] [Federal Constitutional Court] July 30, 2019, 151 ENTSCHEIDUNGEN DES BUNDESVERFASSUNGSGERICHTS [BVERFGE] 202, 291, 293 (Ger.) (considering that the establishment of independent agencies must be specially justified and compensated by an effective judicial control).

195. Regarding Germany and the U.S., see OSTER, supra note 5, at 152-53, 315.

196. Regarding the United States, see, for example, Nathan Alexander Sales \& Jonathan H. Adler, The Rest is Silence: Chevron Deference, Agency Jurisdiction, and Statutory Silences, 2009 U. ILL. L. REV. 1497, 1543-48. 
precise rules that minimize the scope of interpretation. Among these possibilities, it is at best unclear why the legislature would choose vague rules with more responsibility for the agencies to interpret them.

In reality, members of a parliament often adopt vague legislation either because they cannot agree on more precise terms, they are not sure of the practical implications, or they would rather have agencies and courts perform this task. ${ }^{197}$ Strategic vagueness on the part of Parliament, in favor of agencies as opposed to courts, does not seem to be empirically founded. ${ }^{198}$ In any event, this peculiar objection against judicial deference does not derive from constitutional norms in the countries where it is raised.

\section{The Room for Deference}

Considering the foregoing, there may be room for judicial deference to administrative statutory interpretation, within the applicable international, constitutional, statutory, and other limits (subpart A). An important, and perhaps the most convincing, justification for such a deference lies in the asymmetry of non-legal expertise (subpart B). Based on several criteria, the room for deference may be more precisely defined (subpart C). Finally, some specific comments will be made regarding Canada and the United States (subpart D).

\section{A. International, Constitutional, Statutory, and Other Limits}

As explained above, ${ }^{199}$ any judicial deference to administrative statutory interpretation has to comply with the applicable international, 200 constitutional, 201 and statutory limits. Other

197. Regarding the United States, see, for example, Bednar \& Hickman, supra note 49 , at $1454-55$

198. On judicial deference to reasonable agency interpretations of ambiguous regulations in the United States, see, by analogy, Cass R. Sunstein \& Adrian Vermeule, The Unbearable Rightness of Auer, 84 U. CHI. L. REv. 297, 308 (2017).

199. See supra Parts III.B, V.C-D.

200. On the conformity of national law with European Union (EU) law for EU Member States, see, for example, OSTER, supra note 5, at 161-65, 242-43.

201. Regarding the German Basic Law (Article 19 Sect. 4 in particular), see, for example, Bundesverfassungsgericht [BVERFG] [Federal Constitutional Court] May 31, 2011, 129 ENTSCHEIDUNGEN DES BUNDESVERFASSUNGSGERICHTS [BVERFGE 1, 21-23 (Ger.); Aschke, supra note 30, ๆ 106; Bosch, supra note 62, at 108-14; Schmidt-Aßmann, supra note 60, ๆ 180-85c. Regarding the Swiss Federal Constitution, see, for example, SCHINDLER, supra note 6, at 339. Regarding the Constitution of the United States, see, for a fundamental critic of Chevron deference, Hamburger, supra note 57, at 1249-50 ("The Constitution vests judicial power in the courts, and it staffs the courts with judges - that is, with persons who have an office of independent judgment. Judges, in adjudicating their cases, thus have the duty to exercise their own independent judgment 
constraints may flow from general principles or notions such as the rule of law. ${ }^{202}$ Courts must ensure that administrative bodies remain within these limits or constraints. ${ }^{203}$ As described, limits are usually rather vague, and their precise meaning is determined through interpretation. Courts cannot avoid this step before determining whether to defer to administrative statutory interpretation and, if so, to what extent.

The first set of limits relates to courts' constitutional role. Constitutional provisions in this respect, especially as far as statute interpretation is concerned, are unclear in most countries. To a certain extent, the responsibility belongs to courts themselves to determine the exact outline of their role. ${ }^{204}$ Unless there are convincing supporting arguments, advice against overinterpreting very general constitutional norms may prove sound. There may, however, be historical, cultural, or constitutional differences between countries that justify a particular role of the judiciary. All things considered, one should expect that courts effectively adhere to the principles they infer from the constitution. Between a system of judicial review where courts consider that the constitution permits some limited deference and act accordingly, and a system where courts take the position that they are not allowed any deference, but unconsciously or consciously sometimes defer to administrative bodies, one may find the first more satisfactory, transparent, and constitutionally appealing. In this perspective, courts should state what they $\mathrm{do}^{\mathbf{2 0 5}}$ and what they are actually able to do.

The second set of limits comes from procedural safeguards and other rights guaranteed by international human rights, when applicable, as well as national constitutions. ${ }^{206}$ These limits have an important impact on the intensity of judicial review, but they do not necessarily exclude any type of deference. ${ }^{207}$ Courts should carefully verify whether and, if so, to what extent the applicable procedural safeguards allow them to defer to administrative statutory interpretation. These safeguards notably relate to the fairness of the

about what the law is, including their own independent judgment about the interpretation of the law. Accordingly, when judges defer to agency judgments about statutory interpretation, the judges abandon their very office or duty as judges.").

202. Regarding Canada, see Canada (Minister of Citizenship \& Immigr.) v. Vavilov, 2019 S.C.C. 65 , paras. 53-64 (2019).

203. Regarding Germany, see, for example, Beaucamp, supra note 6, at 197.

204. See supra Part V.C.

205. See DALY, supra note 16, at 288.

206. From a comparative perspective, see Lindseth, supra note 60, at 190. Regarding the German Basic Law, see, for example, OsTER, supra note 5, at 51-52, 16566.

207. See supra Part V.D. 
decision-making process ${ }^{208}$ and are usually of a constitutional or equivalent nature. Courts may also take into account the characteristics of the proceedings before the administrative body itself. When the latter acts impartially as well as independently and parties are largely involved and enjoy procedural safeguards in these proceedings, some judicial deference may be considered as admissible from a constitutional or a human rights standpoint. ${ }^{209}$ These elements may indeed contribute to considering that judicial proceedings, in case of an appeal against the administrative decision, remain fair even if there is some judicial deference. In Europe, compliance with the right to a fair trial based on Article 6 par. 1 ECHR is assessed on the basis of "the entirety of the proceedings conducted in the domestic legal order."210

The third set of limits is composed of statutory provisions dealing with the relationship between administrative bodies and courts and, more precisely, with the standard of review which the latter must apply. Statutes regarding administrative procedure in particular may prevent courts from deferring to administrative decisions. Few clear-

208. Regarding Canada, see LeWANs, supra note 16, at 221. Regarding Germany, see, for example, Hoffmann-Riem, supra note 4, at 749-50; Voßkuhle, supra note 65, at 118.

209. In case law of the European Court of Human Rights, see, for instance, Tsanova-Gecheva v. Bulgaria, Eur. Ct. H.R. App. No. 43800/12 para. 98 (2015). Regarding Germany, see Bosch, supra note 62, at 49, 386. Regarding the United Kingdom and Australia, see Aronson, supra note 91, at 261 ("English and Australian courts go more lightly on court-like bodies because they are like courts, and because they are independent of government."); see also Allan, supra note 106, at 45-53 ("The quality of the administrative process, insofar as it can be demonstrated, will enhance the court's confidence that the ultimate outcome [where there is scope for reasonable differences of judgement] falls within the permitted range. For the court is inevitably dependent, in large part, on the inquiries and deliberation undertaken by the authority; and the closer the correspondence between the type of inquiry conducted by the authority and the style of analysis appropriate for courts, the more readily the court can be satisfied that all relevant considerations have been duly taken into account and properly weighed or assessed." (quotation from page 47)).

210. In case law of the European Court of Human Rights, see, for instance, Gil Sanjuan v. Spain, Eur. Ct. H.R. App. No. 48297/15 para. 30 (May 26, 2020), http://hudoc.echr.coe.int/eng\#\{"fulltext":["Sanjuan\%20v.\%20Spain"],"documentcollectio nid2":["GRANDCHAMBER","CHAMBER"],"itemid":["001-202539"]\} (last visi-ted Dec. 10, 2020) [https://perma.cc/NDM3-R4A5] (archived Dec. 10, 2020); Pasquini v. San Marino, Eur. Ct. H.R. App. No. 50956/16 para. 89 (May 2, 2019), http://hudoc.echr.coe.int/eng\#\{"fulltext":["Pasquini\%20v.\%20San\%20Marino"],"docume ntcollectionid2":["GRANDCHAMBER","CHAMBER"],"itemid":["001-192787"]\} （last visited Dec. 10, 2020) [https://perma.cc/M2VB-XK7M] (archived Dec. 10, 2020); Zubac v. Croatia, Eur. Ct. H.R. App. No. 40160/12 para. 82 (April 5, 2018), http://hudoc.echr.coe.int/eng\#\{"fulltext":["Zubac\%20v.\%20Croatia"],"documentcollection id2":["GRANDCHAMBER","CHAMBER"],"itemid":["001-181821"]\} [https:// perma.cc/3X7H-RFWX] (archived Dec. 10, 2020); see also EUROPEAN COURT OF HUMAN Rights, GUIDE ON ARTICle 6 (CRIMINAL LIMB), supra note 183, paras. 282, 303-04; EuROPEAN COURT OF HUMAN RIGHTS, GUIDE ON ARTICLE 6 (Civil LIMB), supra note 183, paras. 57, 151, 275, 287, 292, 327, 359, 411. 
cut provisions on this issue seem to exist in the many countries that have been considered in this Article. ${ }^{211}$

In several countries, the applicable limits to judicial deference may actually lead to a nuanced approach. Administrative statutory interpretation of deep legal, political, or economic significance or of general questions of central importance to the legal system as a whole, may, for instance, be subject to judicial review without any deference. However, interpretation with a more constrained impact may not, provided that neither the applicable standard of review nor procedural safeguards impose an unrestrained judicial review.

\section{B. Asymmetry of Non-Legal Expertise}

The case for or against judicial deference to administrative statutory interpretation raises many issues. When the applicable international, constitutional, statutory, and other limits leave some room to such deference, the asymmetry of non-legal expertise can be regarded as an important or, depending on the country, even decisive element. ${ }^{212}$ It may actually have substantive and procedural

211. Regarding the "unclearness" of Section 706 of the US Administrative Procedure Act (APA), see Sunstein, supra note 60, at 1642-44.

212. From a comparative or general perspective, see, for example, Zhu, supra note 16, at 11-12; Reitz, supra note 3 , at 298 (“. . . de facto deference may well be universal, especially deference on the grounds of governmental expertise."); JORDÃO, supra note 16 , at $152-53,305-06,568$; DALY, supra note 16 , at 72-89; Tolley, supra note 84, at 437-38; see also Allan, supra note 106, at 43 ("When there is scope for different answers or approaches, it is right that the court accept the solution favoured by the public authority. Not only may the authority possess an expertise that the court itself lacks, but it will normally be publicly accountable in ways that judges are not."). Regarding Australia, in a prospective way, see Boughey, supra note 43, at 36-37, 45-47, 53; Regarding Canada, see Frank A. V. Falzon, Statutory Interpretation, Deference and the Ambiguous Concept of "Ambiguity" on Judicial Review, 29 CAN. J. ADMIN. L. \& PRAC. 135, 142 (2016). Regarding China, see Gao, supra note 145, at 125-29. Regarding France, in a prospective way, see Autin, supra note 155, at 294. Regarding Germany, see, for example, Oster, supra note 4, at 1294; BoscH, supra note 62, at 47-50; Hoffmann-Riem, supra note 4, at 743-45; see also Christoph Möllers, Materiellrechtliche Bindungen unabhängiger Regulierungsbehörden [Substantive Norms Binding Regulation Authorities], in INDEPENDENT REGULATION AUTHORITIES, supra note 2, at 231, 257-58 (insisting on the complexity of fact processing and time pressure that courts face). Regarding Japan, even though deference does not relate to interpretation of statutes as such, see Kawagishi, supra note 35, at 317-19. Regarding Switzerland, see SCHINDLER, supra note 6, at 338-39, 341-62. Regarding Taiwan, see Cheng-Yi Huang, Judicial Deference to Agency's Discretion in New Democracies: Observations on Constitutional Decisions in Poland, Taiwan, and South Africa, in Comparative Administrative LaW, supra note 14, at 478, 482-85. Regarding the United States, see, for example, ESKRIDGE, supra note 99, at 282-83; Dolehide, supra note 102, at 1396; Eskridge \& Baer, supra note 78 , at $1173-74$. 
dimensions, ${ }^{213}$ and is comparative in its nature. ${ }^{214}$ Many other aspects of the debate are linked to it or are rather inconclusive.

In Canada, "asymmetry and specialization" are mentioned by the Supreme Court to justify judicial deference regarding administrative decisions, though the Court does not systematically focus on non-legal expertise and considers that even decisions balancing constitutional values may be subject to such deference. ${ }^{215}$ The Supreme Court also mentions "the different roles of the courts and administrative bodies within the Canadian constitutional system." ${ }^{216}$ More precisely, a question of law, which was not of central importance to the legal system, could nonetheless be compatible with a reasonableness standard where there was a privative clause (i.e., "a statutory direction from Parliament or a legislature indicating the need for deference"), or in the case of a "discrete and special administrative regime in which the decision maker has special expertise." ${ }^{217}$ According to a recent landmark decision, the Supreme Court now presumes that "reasonableness is the applicable standard in all cases," and "[r] eviewing courts should derogate from this presumption only where required by a clear indication of legislative intent or by the rule of law."218 While the relative expertise of administrative decision-makers "is no longer relevant to a determination of the standard of review,"219 it "remains a relevant consideration in conducting reasonableness review." 220 This relates, inter alia, to the interpretation by an

213. Regarding the United States, see Adrian Vermeule, Deference and Due Process, 129 HARV. L. REV. 1890, 1893, 1915-16, 1919-21, 1931 (2016) (“Under resource constraints, agencies must design procedures with a view to substance, and vice versa. Hence procedure and substance, whether or not conceptually distinct, are pragmatically inextricable, and agencies must calibrate both margins simultaneously. Agency authority over substance, explicitly or implicitly delegated by Congress and justified by agency expertise, necessarily implies authority over procedure as well." (quotation from page 1931))

214. Regarding the United States, see VERMEULE, supra note 41, at 156.

215. Doré v. Barreau du Québec [2012] 1 S.C.R. 395, para. 47 (Can.); see also Loyola High School v. Québec (Attorney General) [2015] 1 S.C.R. 613, paras. 4, 35-42. On this case law, see, for example, Daly, Deference on Questions of Law, supra note 14, at 707 ("The best answer to a question of law might come from a delegated decisionmaker more familiar than a court with the particular area of law."); LEWANS, supra note 16, at 181-82. For a nuanced and somehow dubitative view in this respect, see Aronson, supra note 91, at 247-48, 261.

216. Dunsmuir v. New Brunswick [2008] 1 S.C.R. 190, para. 55 (Can.).

217. Dunsmuir, [2008] 1 S.C.R. 190, para. 47; see also Smith v. Alliance Pipeline Ltd. [2011] 1 S.C.R. 160, paras. 26-40 (Can.). On this case law, see, for example, Paul Daly, Struggling Towards Coherence in Canadian Administrative Law? Recent Cases on Standard of Review and Reasonableness, 62 MCGILL L.J. 527, 532, 540 (2016) [hereinafter Daly, Struggling Towards Coherence]; Craig, supra note 11, at 399-400, 402-03 (agreeing with this approach).

218. Canada (Minister of Citizenship and Immigration) v. Vavilov, 2019 S.C.C. 65 , para. 10 (Can.).

219. Id. para. 31 .

220. Id. paras. 31, 93. 
administrative body of the statute it administers, except when "constitutional questions, general questions of law of central importance to the legal system as a whole and questions related to the jurisdictional boundaries between two or more administrative bodies" are at stake. ${ }^{21}$ Furthermore, the asymmetry of expertise may also play a role even when correctness is the applicable standard of review, as mixed questions of law and fact are subject to a deferential standard. ${ }^{222}$ Finally, expertise and institutional experience may be a reason "for the legislature to delegate the administration of a statutory scheme to a particular administrative decision maker." ${ }^{223}$ In this regard, putting responsibility and accountability on the legislature appears quite sound in a democratic system.

In the United Kingdom, the Supreme Court has rendered relevant decisions according deference with regard to tribunals. ${ }^{224}$ According to the relevant case law, there are limits to substitution of judgment with regard to questions of law in cases where decisions of a tribunal are challenged before a court. ${ }^{225}$ There is not yet a definitive case as to whether the same reasoning might apply in other contexts, for instance in the case of an agency with expertise in its particular assigned field. It is difficult to predict whether the Supreme Court of the United Kingdom would extend its reasoning to such a situation, or whether it would confine it to the sphere of tribunals. Arguments could weigh in favor of either side, and a nuanced approach may be appropriate. ${ }^{226}$ Considering especially agencies' special expertise, prominent scholars favor extension of the reasoning outside this sphere. ${ }^{227}$

221. Id. paras. 17, 53, 119 ("The specialized expertise and experience of administrative decision makers may sometimes lead them to rely, in interpreting a provision, on considerations that a court would not have thought to employ but that actually enrich and elevate the interpretive exercise."). The second and third categories of questions are especially relevant with respect to the interpretation of statutes.

222. See Paul Daly, The Vavilov Framework and the Future of Canadian Administrative Law, 33 CAN. J. ADMIN. L. \& PRAC. 111, 121 (2020) ("It is, nonetheless, difficult to be categorical about the likely consequences of Vavilov for economic regulation and professional discipline, where the expertise of decision-makers is wellestablished as a matter of social fact even if it is henceforth irrelevant as a matter of legal doctrine. Much will depend, therefore, on the willingness of first-instance judges to categorize matters coming within the expertise of regulators as questions of law [subject to correctness review] or as mixed questions [subject to review for palpable and overriding error] ..... And one wonders whether, despite the injunction to perform correctness review on extricable questions of law, courts hearing appeals from specialized administrative decision-makers will nevertheless give significant or perhaps even dispositive weight to the decision-makers' views on matters within their expertise. Deference might not be dead yet."(footnote omitted)).

223. Vavilov, 2019 S.C.C. 65, para. 29.

224. See, e.g., R (Cart) v. Upper Tribunal [2011] UKSC 28; R (Jones) v. First Tier Tribunal [2013] UKSC 19.

225. See R (Cart), [2011] UKSC at [43]; $R$ (Jones), [2013] UKSC at [44].

226. See, e.g., Aronson, supra note 91 , at 253.

227. See, e.g., Craig, supra note 14, at 391-94, 402-03. 
In the European Union, the specific expertise of the European Commission-specifically of the Directorate-General (DG) for Competition-may lead to some judicial deference in complex economic appraisals relevant for the interpretation of competition law norms, though it is now considered that said appraisals are subject to full judicial review. ${ }^{228}$

The asymmetry of expertise between administrative bodies and courts may first and foremost play a role when the interpretation of statutory provisions requires technical, economic, or scientific expertise in particular. The term "non-legal expertise" may seem counterintuitive or even inapt in this context, as expertise usually refers to facts rather than law. However, the point is made here that technical expertise, for instance, may be useful or even required to interpret some statutory provisions. ${ }^{229}$ In the United States, the Supreme Court has suggested that the relevant experience and expertise may extend to the interpretation of complex statutory schemes of regulation. ${ }^{230}$ For instance, the term "dangerous substances" used in a statute needs to be interpreted. This task very likely requires having deep theoretical and empirical knowledge of chemistry, biology, and other scientific fields, as well as of the various factual situations in which the application of the provision in question can be considered. The distinction between law and fact definitely comprises a grey zone, ${ }^{231}$ not least because some issues raise mixed questions of law and fact. ${ }^{232}$ Indeed, the prohibition on "dangerous

228. See Schweitzer, supra note 131, at 509-11, 531-33, 537-38 (noting the evolution in the case law of the European Court of Justice and concluding, on page 538, with these words: "Whether there is a need to adapt the procedural framework or practice to the new challenge of ensuring full judicial review in the light of an increased use of complex economic methodologies is a matter of debate. In some cases, courts may want to make broader use of court-appointed experts in the future. Yet, the greatest difficulty may not lie in understanding economic theories typically presented in some clarity by the parties, but in aptly translating them into law. This is a genuinely legal task." (footnotes omitted)).

229. Regarding the United States, see Sunstein, supra note 60, at 1626-29, 1673 (distinguishing between "purely legal expertise" and "technical expertise"); TUSHNET, supra note 122, at 159 ("Whatever the case for Chevron itself, it does seem true that for highly technical judgments, agency expertise is often helpful in figuring out the best interpretation of a statute.").

230. See United States v. Mead, 533 U.S. 218, 227-28, 235 (2001); Barnhart v. Walton, 535 U.S. 212, 222, 225 (2002).

231. See, e.g., Daly, supra note 14 , at 705 .

232. Regarding Canada, see, for example, Canada (Minister of Citizenship and Immigration) v. Vavilov, 2019 S.C.C. 65, para. 37 (Can.). Regarding the United States, see, for example, The Chevron Doctrine: Constitutional and Statutory Questions in Judicial Deference to Agencies: Hearing Before the Subcomm. on Regulatory Reform, Commercial and Antitrust Law of the H. Comm. on the Judiciary, 114th Cong. 41 (2016) (prepared statement of John F. Duffy, Professor of Law, University of Va. L. Sch.) ("Congress might also consider recognizing the traditional view that, in formal agency adjudicatory proceedings, some issues decided by the agency are not pure issues of 
substances" raises countless factual issues, but the relevant administrative body must also determine criteria to evaluate a substance's danger and set limits beyond which a prohibition is justified. ${ }^{233}$ In other words, it must not only determine whether some substances are dangerous, but also-at least to a certain extentdefine what "dangerous" means. By doing so, it interprets or constructs the relevant statute. The same can be said of the term "relevant market" widely used in competition law. What is a market? What does relevancy mean? Criteria based on economic theories and data analysis must be defined in order to answer these questions and interpret these terms. ${ }^{234}$

Of course, the difference between legal and non-legal expertise is vague. Judges should determine at what moment they get out of their actual and-from the legislature-reasonably expected zone of expertise. When they act accordingly in an honest, reasoned, and transparent manner and comply with the applicable international, constitutional, statutory, and other constraints, they are up to their judicial task ${ }^{235}$ and create valuable case law. The test cannot be subjective, as it would produce personal and unpredictable results; judicial deference should not depend on each judge. Accordingly, judges must, to a certain extent at least, carefully objectivize and institutionalize the notion of asymmetry of expertise and, hence, the concept of judicial deference. ${ }^{236}$ In Germany, for example, certain administrative decisions are complex and based on ongoing developments, where courts reach their functional limitations; ${ }^{237}$ a licensing procedure for a nuclear power plant provides a good illustration here. ${ }^{238}$

statutory interpretation but are instead mixed questions of law and fact. For such questions, a reviewing court might provide deference to the agency not because of the agency's abilities at statutory interpretation, but because of the agency's superior ability to apply a statutory concept to the specific factual context in that adjudication.").

233. For similar examples, see Bednar \& Hickman, supra note 49, at 1448.

234. See Viktoria H. S. E. Robertson, The Relevant Market in Competition Law: A Legal Concept, 7 J. ANTITRUst ENForCEMENT 158 (2019). In the European Union, see the Commission Notice on the Definition of Relevant Market for the Purpose of Community Competition Law, 1997 O.J. (C 372/5) (this notice has been subject to a public consultation in 2020 and may be updated in 2021).

235. Regarding the UK, see Rebecca Williams, When is an Error Not an Error? Reform of Jurisdictional Review of Error of Law and Fact, 2007 PUB. L. 793, 799.

236. From a comparative perspective, see JORDÃO, supra note 16, at 541-42; see also DALY, supra note 16, at 86; Tan, supra note 179, at 400 ("Any claims of specialised knowledge or expertise must be rigorously tested."). Regarding Canada, see Edmonton (City) v. Edmonton East (Capilano) Shopping Ctrs. Ltd., [2016] 2 S.C.R. 293, para. 33 (Can.).

237. See, e.g., Oster, supra note 4, at $1275,1294$.

238. Bundesverfassungsgericht [BVERFG][Federal Constitutional Court] July 8, 1982, 61 ENTSCHEIDUNGEN DES BUNDESVERFASSUNGSGERICHTS [BVERFGE] 82, 110-16 (Ger.). 
The asymmetry of non-legal expertise is especially of importance when the interpretation of statutory provisions explicitly or implicitly requires making some predictions in uncertain situations or specific appraisals or assessments. ${ }^{239}$ Interpretation of the words "dangerous," "feasible," "reasonable," or "apt" may illustrate this point, notably in the United States, especially when they are used in a context that requires such expertise. ${ }^{240}$ There is a difference between the statutory ban of "violent video games" for minors and the one of "video games likely to cause violent behaviors" in countries where the constitution allows such prohibitions. Ceteris paribus, judicial deference may be admissible solely or particularly for the interpretation of the second type of prohibition.

The initial asymmetry of non-legal expertise does not mean that courts do not carry any responsibility to correct it, partially or completely depending on the case. ${ }^{241}$ Courts should in principle not presume it ${ }^{\mathbf{2 4 2}}$ - Canada may partly be a special case here ${ }^{\mathbf{2 4 3}}$ - and can

239. Regarding Germany, see, for example, Oster, supra note 4, at 1272 ("Indefinite legal terms [unbestimmte Rechtsbegriffe] are terms that require a valuation. Mostly there is no assured scientific knowledge to conclude if a certain statutory requirement is met or not . . . Strictly speaking, these are not legal terms, but terms from natural, economic or other sciences used in a statute."). Regarding the United States, see Sunstein, supra note 60, at 1628 (raising the following hypotheses: "If . . . ambiguities cannot be resolved without the application of technical expertise, the pragmatic argument for Chevron would be more forceful. So too if resolution of ambiguities would not be possible without resort to judgments of value that are best made by a politically accountable entity." (footnote omitted)); see also, from a broader perspective, Eskridge \& Baer, supra note 78, at 1174 ("Typically, agencies are much better equipped to handle issues of uncertainty than courts are.").

240. Regarding the United States, see Jeffrey A. Pojanowski, Neoclassical Administrative Law, 133 HARV. L. REV. 852, 893 (2020) (referring, with respect to judicial deference, to "cases in which there is no surface upon which traditional lawyers' tools can have purchase, such as commands that the agency be 'reasonable' or act 'in the public interest' when those phrases are not terms of art"); Kavanaugh, supra note 106, at 2153; Bednar \& Hickman, supra note 49, at 1448-49.

241. Regarding Germany, see Aschke, supra note 30, para. 130.

242. Regarding Canada, see Joseph T. Robertson, Administrative Deference: The Canadian Doctrine that Continues to Disappoint 68 (Apr. 18, 2018) (unpublished manuscript), https://papers.ssrn.com/sol3/papers.cfm?abstract_id=3165083 [https: //perma.cc/R7XH-F6XU] (archived Sept. 27, 2020). Regarding Germany, see Klaus Schönenbroicher, $\S 40$, in VERWALtUNGSVERFAHRENSGESETZ [ADMINISTRATIVE PROCEDURE ACT] para. 94 (Thomas Mann, Christoph Sennekamp \& Michael Uechtritz eds., 2d ed. 2019). Regarding the United Kingdom, see Allan, supra note 106, at 51; Aileen Kavanagh, Defending Deference in Public Law and Constitutional Theory, 126 L.Q. REV. 222, 226 (2010) ("[T] he question about relative competence, expertise and legitimacy must be judged on a case-by-case basis, taking into account all the contextual factors relevant to the deference inquiry.").

243. See Edmonton (City) v. Edmonton East (Capilano) Shopping Ctrs. Ltd., [2016] 2 S.C.R. 293, para. 33 (Can.) ("[A]s with judges, expertise is not a matter of the qualifications or experience of any particular tribunal member. Rather, expertise is something that inheres in a tribunal itself as an institution. ..."). But see, in this case, the joint dissenting opinion. Edmonton East (Capilano) Shopping Ctrs., [2016] 2 S.C.R. 
appoint experts where and when they are validly required to do so or deem it necessary. Nevertheless, the systematic appointment of experts to deal with the subject matter of all challenged administrative statutory interpretations is neither realistic nor appropriate from a cost, efficiency, or even justice perspective. ${ }^{244}$ In a challenge to a statute's interpretation, should an expert really be appointed if no clear and potentially decisive argument is brought? ${ }^{245}$ The asymmetry of non-legal expertise must ultimately be assessed after taking into account the reasonable and realistic possibility of appointing experts in the relevant fields. ${ }^{246}$

The mere asymmetry of non-legal expertise does not necessarily mean that administrative statutory interpretation should, in most cases, benefit from judicial deference. Such a general approach would most likely not fit within the constitutional ${ }^{247}$ and legal framework of many countries. To be constitutionally admissible, judicial deference has to be framed by criteria and assessed in the relevant context.

\section{Conceivable Criteria for Deference}

Several criteria, needed to admit judicial deference to administrative statutory interpretation, are conceivable. They differ depending on whether the legislature has explicitly or actively (1) or only implicitly or passively (2) enabled courts to exercise such deference.

\section{Explicitly or Actively Enabling Judicial Deference}

Judicial deference to administrative statutory interpretation may explicitly be imposed or permitted by statute. In such a case, courts

293, para. 85 (Côté and Brown, JJ., dissenting) ("Courts must not infer from the mere creation of an administrative tribunal that it necessarily possesses greater relative expertise in all matters it decides, especially on questions of law."). In the recent Vavilov decision, the Supreme Court seems to insist on "demonstrated experience and expertise." Canada (Minister of Citizenship and Immigration) v. Vavilov, 2019 S.C.C. 65, para. 93 (Can.). Regarding the presumption of deference in Canada, see supra Part III.C.

244. See JORDÃO, supra note 16, at 214-15.

245. Regarding Germany, see Bosch, supra note 62 , at $73-74,385-86$, who provides an answer to this question in the negative.

246. Regarding Germany, see Aschke, supra note 30, ๆ $130-31$.

247. Regarding Germany, see Bundesverfassungsgericht [BVerfG][Federal Constitutional Court] May 31, 2011, 129 ENTSCHEIDUNGEN DES BundesverfassungsGerichtS [BVERFGE] 1, 22-23 (Ger.); Aschke, supra note 30, I 130; see also Markus Ludwigs, Verfassung im Allgemeinen Verwaltungsrecht: Bedeutungsverlust durch Europäisierung und Emanzipation? [Constitution in General Administrative Law: Loss of Significance Due to Europeanization and Emancipation?], 2015 NEUE ZEITSCHRIFT FÜR VERWALTUNGSRECHT [NEW J. FOR ADMIN. L.] 1327, 1329 and Schmidt-Aßmann, supra note 60, $\uparrow 191$, who both refer to Article 19, § 4 of the German Basic Law (access to courts). 
still have to verify that the relevant statute does not violate the constitution or international law in countries where the supremacy of the one or the other over statutes is legally enforceable. A general authorization of judicial deference, granted by the legislature, may prove unconstitutional or contrary to general principles such as the rule of law in many countries; accordingly, the legislature would have to consider the situations in which judicial deference specifically makes sense and is authorized or enabled. However, an explicit and specific authorization does not mean that courts do not face difficult questions.

Firstly, when courts are expressly allowed but are under no obligation to defer to administrative statutory interpretation, they must define criteria under which they will use this option. ${ }^{248}$ The statutory provision must, therefore, be interpreted with the applicable methods and canons of construction. If this does not lead to clear results, courts may then refer to the criteria below relating to situations where the legislature has implicitly, or even passively, enabled judicial deference. ${ }^{249}$

Secondly, the precise intensity of deference is most likely not defined in the relevant statute. Courts themselves must address this issue. ${ }^{250}$ There may be a gradation in intensity depending on the types of cases subject to judicial review. The highest level of intensity of deference could occur when the criteria below are cumulatively met. ${ }^{251}$

Speaking of "explicitly or actively enabling judicial deference" rather than only of "explicitly enabling judicial deference" is preferred in this Article. The two adverbs should largely be considered as synonymous, but not completely. There may be situations where the interpretation of a statute according to the applicable methods and canons of construction clearly and unequivocally leads to the conclusion that the legislature specifically addressed the issue of judicial deference and wanted courts to defer to administrative statutory interpretation, though no explicit wording was formulated in the relevant statute. ${ }^{252}$ In such a situation, one may consider that the authorization was active, though not explicit. In some countries, a statute can contain a so-called "qualified silence" which has normative value. ${ }^{253}$ In others, a textual interpretation of statute precludes or limits such an approach.

248. See, e.g., Kavanagh, supra note 242, at 223.

249. See infra Part VI.C.2.

250. Regarding Switzerland, see SCHINDLER, supra note 6, at 383.

251. See infra Part VI.C.2.

252. Regarding Germany, see Bosch, supra note 62, at 121.

253. Regarding Switzerland, see, for instance, Bundesgericht [BGer] Oct. 18, 2011, 138 ENTSCHEIDUNGEN DES SCHWEIZERISCHEN BUNDESGERICHTS [BGE] II 1, 4 (Ger.); MOOR, FLÜCKIGER \& MARTENET, supra note 29, at 150. 


\section{Implicitly or Passively Enabling Judicial Deference}

From a comparative perspective, there are very few examples of active authorization for courts to defer to administrative statutory interpretation. In most countries considered in this Article, the authorization or, better, the enablement is regarded, at best, as implicit or passive, depending on the country or the circumstances. This supposes that the applicable international, constitutional, statutory, and other constraints leave room for such deference.

The three initial steps of judicial analysis consist of determining whether a statute allows a margin of interpretation or construction in light of the applicable methods and canons of construction, ${ }^{254}$ verifying that the administrative statutory interpretation remains within this margin, and carefully interpreting and respecting the applicable international, constitutional, statutory, and other constraints framing the potential for deference, generally or in the individual case. ${ }^{255}$ The distinction between clarity and ambiguity of a statute is itself blurry and subject to different opinions and interpretations, ${ }^{256}$ and courts should really strive to find the meaning of a statute. ${ }^{257}$ Nevertheless, there may be situations where, despite judges' best efforts and good will, a statutory provision really allows a margin of interpretation in light of the applicable methods and canons of construction, ${ }^{258}$ (i.e., in light of the various interpretive principles and not only the textual ones). ${ }^{259}$ One could argue that the first step is unnecessary and that courts should directly assess whether the administrative interpretation remains compatible with the applicable methods and canons of construction. Interpretation of the law is, however, a fundamental judicial task, and courts bear a responsibility in this respect. Hence, deference should not be the starting point-the applicable legal regime may, however, be special in a given country-

254. On this issue, see, for example, Scalia, supra note 153, at 517, 520-21.

255. On this issue, see JORDÃO, supra note 16, at 567-70.

256. Regarding the United States, see, for example, Richard M. Re, Clarity Doctrines, 86 U. CHI. L. REV. 1497, 1505-21 (2019). With respect to Chevron, see id. at 1531-40.

257. Regarding the United States, see especially Kavanaugh, supra note 106, at 2134-56; see also Sunstein, supra note 60, at 1672-73. In a recent decision relating to the interpretation of an agency's regulations, but quoting the Chevron decision, the Supreme Court made clear that "before concluding that a rule is genuinely ambiguous, a court must exhaust all the 'traditional tools' of construction." Kisor v. Wilkie, 139 S. Ct. 2400, 2415 (2019) (citation omitted).

258. From a comparative perspective, see Daly, Deference on Questions of Law, supra note 14, at 700-01. Regarding Canada, see Falzon, supra note 212, at 145-49. Regarding the United States, see Sunstein, supra note 60, at 1673 ("[S]ome ambiguities are real and others are merely apparent. They disappear on reflection.”).

259. Regarding Canada, see Robertson, supra note 242 , at 67. 
and the sole focus should not lie on the administrative body's interpretive task.

There should be, in principle, no judicial deference with respect to these three steps, ${ }^{\mathbf{2 6 0}}$ which also ensure that administrative bodies are ultimately bound to the same methods and canons of construction ${ }^{261}$ and that their interpretation of a statute is neither unreasonable nor arbitrary. ${ }^{262}$ There may be strong arguments against the idea that administrative bodies, in which lawyers do not necessarily have the final say, should apply the same methods and canons of construction as courts. ${ }^{263}$ In difficult cases, where appeals come almost certainly, they have to convince judges ${ }^{264}$ and must, at least, follow judicial precedent and remain sensitive to judicial methods of interpreting laws. ${ }^{265}$ It does not make them "master[ies] of the principles of

260. Regarding the first step in the United States, see Sunstein, supra note 60, at 1679 (" $[\mathrm{I}] \mathrm{t}$ is both correct and important to insist that it is for judges, not agencies, to decide whether statutes contain ambiguities, and whether they delegate lawinterpreting power."); see also CASS R. SUNSTEIN \& ADRIAN VERMEUlE, LAW \& LEVIATHAN: REDEEMING THE ADMINISTRATIVE STATE 136, 138 (2020).

261. On this point, see, regarding Australia, Cane, supra note 91, at 238 ("[B]oth normatively and strategically, administrators should approach interpretation in precisely the way a court would, applying the same rules, principles and modes of reasoning." (footnote omitted)); regarding Canada, Canada (Minister of Citizenship \& Immigration) v. Vavilov, 2019 S.C.C. 65, para. 120 (Can.) ("But whatever form the interpretive exercise takes, the merits of an administrative decision maker's interpretation of a statutory provision must be consistent with the text, context and purpose of the provision. In this sense, the usual principles of statutory interpretation apply equally when an administrative decision maker interprets a provision.”). See also Paul Daly, The Struggle for Deference in Canada, in The Scope And InTEnsity of SUBSTANTIVE REVIEW, supra note 84, at 297, 322 ("Administrative decision-makers are taught by reviewing courts that it is better to think like lawyers, even if the legislature's goal of empowering administrative decision-makers in the first place was to avoid having decisions made by people who think like lawyers." (footnote omitted)).

262. On this last point, see OSTER, supra note 5, at 313; Sunstein, supra note 60, at $1673,1678$.

263. Regarding Canada, see Daly, Unreasonable Interpretations of Law, supra note 28 , at 257-58, 264-66 (considering that "[a]n applicant for judicial review must first identify indicia of unreasonableness that afflict a decision" such as "[i]llogicality, inconsistency with statutory purpose or underlying values, differential treatment and unexplained changes in policy"). Are these elements not some of the ones that are covered by the applicable methods and canons of construction in many jurisdictions? On the interpretation with the help of logical arguments, see, from a combined (Austrian, German \& Swiss) perspective, ERNST A. KRAMER, JURISTISCHE METHODENLEHRE [LEGAL METHODOLOGY] 183-84, 194-96 (6th ed. 2019); see also, from an Austrian perspective, FRANZ BYDLINSKI \& PETER BYDLINSKI, GRUNDZÜGE DER JURISTISCHEN METHODENLEHRE [FundAMENTALS OF LEGAL METHODOLOGY] 52-55 (3rd ed. 2018).

264. Regarding Canada and the United States, see Paul Daly, Doubts About Deference: Chevron USA v. Natural Resources Defence Council, 32 CAN. J. ADMIN. L. \& PRAC. 137, 147 (2019).

265. Regarding English and Australian law, see CANE, supra note 172, at 236-38. Regarding the United Kingdom, see Craies on Legislation: A PraCtitioners' Guide TO THE NATURE, PROCESs, EFFECT AND INTERPRETATION OF LEGISLATION 737-38 (Daniel Greenberg ed., 11th ed. 2017). 
technical textualism," ${ }^{266}$ as various methods-not just this last oneand canons of construction may come into play. ${ }^{267}$ True, it is possible that no consensus exists among judges on the applicable methods and canons of construction or the way to ponder them. ${ }^{268}$ Each judge should nevertheless interpret a statute by using the methods and canons she allowably considers appropriate and, if no clear conclusion comes out of this process, verify that the administrative interpretation of the relevant statute remains compatible with the same methods and canons.

The obligation to remain within the margin of interpretation ${ }^{269}$ or, in other words, within the "construction zone"270_-determined in light of the applicable methods and canons of construction, does not mean that the administrative body has made the best use of these methods and canons, ${ }^{271}$ but that its statute interpretation is compatible with them or, in other words, remains admissible or defensible in light of them. These criteria represent a way to partly formalize the "reasonableness test" applied in several jurisdictions. ${ }^{272}$ Incidentally, on the basis of these canons, the U.S. Supreme Court

266. Daly, Unreasonable Interpretations of Law, supra note 28, at 266.

267. Regarding Austria, Germany, and Switzerland, see, for example, WANK, supra note 30, at 41-75; KRAMER, supra note 263, at 63-203; BYDLINSKI \& BYDLINSKI, supra note 263, at 27-79; regarding the United Kingdom and, more generally, common law countries, see, for example, DigGoRY BAILEY \& LUKE NORBURY, BENNION ON STATUTORY INTERPRETATION 283-327 (7th ed. 2017).

268. See, e.g., JORDÃO, supra note 16, at 250-51, 370-72. Regarding the United States, see Bednar \& Hickman, supra note 49, at 145-53.

269. Regarding Germany, see Aschke, supra note 30, ๆ 133.

270. See Solum \& Sunstein, supra note 43 , at 1470, 1472, 1475, 1482, 1487; see also Claire R. Kelly, The Brand X Liberation: Doing Away with Chevron's Second Step as Well as Other Doctrines of Deference, 44 U.C. DAVIS L. REV. 151, 189-95 (2010).

271. Regarding the United States, see Little Sisters of the Poor Saints Peter and Paul Home v. Pennsylvania, 140 S. Ct. 2367, 2398-400, 2403 (2020) (Kagan, J., concurring in the judgment).

272. Regarding the United Kingdom, see Williams, supra note 235, at 800-01, 804, 808 (emphasis omitted) (distinguishing "between true jurisdictional error, where the decision-maker fails to reach an objectively verifiable standard and the court can intervene automatically to correct this by substituting the correct answer, and excess of jurisdictional discretion, where the definition and application of a jurisdictional condition such as 'illegal entrant' contains a degree of discretion and the court can only exercise rationality review in accordance with the normal principles, taking account of relative institutional competence along with other advantages and disadvantages of intervention." (quotation from page 808)). On this issue, see also Daly, Struggling Towards Coherence?, supra note 217, at 557 ("Badges of unreasonableness must be identified in order to justify striking down a decision . . . Notably, the indicia of unreasonableness can be drawn from the same sources as the contextual factors that make up the range of reasonable outcomes: inconsistent decisions, for instance, sound in the rule of law; whereas decisions that fail to take into account important statutory language do violence to the democratic principle. And, in general, ensuring that decisions respect the fundamental precepts of the legal system is a means of upholding the rule of law." (footnotes omitted)). 
might have reached the same conclusion in the Chevron case as it did, without needing to develop a specific doctrine of deference. ${ }^{273}$

Should a special and separate "reasonable and not arbitrary test" be additionally conducted if it is not foreseen by the applicable law or case law? Unreasonable or arbitrary statutory interpretation will most certainly conflict with the methods and canons of constructionreasonableness includes, from this perspective, compliance with principles of statutory interpretation ${ }^{274}$ - or the applicable international, constitutional, and statutory constraints. Depending on the jurisdiction, canons of construction, constitutional, and other constraints may anyway single out the same issue. For instance, the absence of deference when statute interpretation raises questions of deep social, economic, and political significance ${ }^{275}$ may be regarded as a canon of construction ${ }^{276}$ or a constitutional constraint. The same can be said of the obligation to interpret a statute so as to stay away from the terrain of constitutional doubt. ${ }^{277}$

Courts must then determine whether the legislature has implicitly or passively enabled them to defer to administrative interpretation of statutes. ${ }^{278}$ There should be no judicial deference to administrative decisions with regard to this issue. ${ }^{279}$ The asymmetry of non-legal expertise between administrative bodies and courts may play an important role in the eyes of the legislature but is not

273. See Cass R. Sunstein, Chevron Without Chevron, 2018 SuP. CT. REV. 59, 7375 (2019).

274. Regarding Canada, see Canada (Minister of Citizenship and Immigration) v. Vavilov, 2019 S.C.C. 65, paras. 115-24 (Can.).

275. Regarding the United States, see King v. Burwell, 576 U.S. 473, 484-87 (2015).

276. Regarding the United States, see Sunstein, supra note 60, at 1675-77.

277. On the "Avoidance Canon" in the United States in this context, see Gluck \& Posner, supra note 3, at 1331-32 ("Thirteen judges . . . singled out lenity and/or constitutional avoidance as 'actual rules' and distinguished them from the other canons, in terms of their mandatory application. They told us that these presumptions are 'not canons' but rather are 'substantive law."'); see also Sunstein, supra note 60, at 1675 . From a general perspective, see Allan, supra note 101, at 55 ("When a statute confers discretion on a public agency ... the limits of that discretion should be construed consistently with legal principles and individual rights, allowing only such minimal encroachment on these principles and rights as is demonstrably necessary to the fulfilment of a legitimate public purpose."). On the constitutionally compliant interpretation of statutes ("verfassungskonforme Auslegung") in Austria, Germany, and Switzerland, which is widely considered as a constitutional constraint, see, for example, WANK, supra note 30, at 59-64; KRAMER, supra note 263, at 116-19; BYDLINSKI \& BYDLINSKI, supra note 263 , at $55,58$.

278. Regarding Germany, see, for example, Hoffmann-Riem, supra note 4, at 746 . Regarding the United States, see, for example, TUSHNET, supra note 122, at 160.

279. Regarding Germany, see Schmidt-Aßmann, supra note 60, I 187; see also Voßkuhle, supra note 65 , at 118. Regarding the United States, see SuNSTEIN \& VERMEULE, supra note 260, at 138 ("[I]t is for judges, not agencies, to decide whether statutes delegate law-interpreting power to administrators, whether statutes contain ambiguities, and whether agencies' resolutions of those ambiguities are reasonable."). 
automatically sufficient. The expertise in question must be relevant to the disputed interpretation of the statute, especially when a prediction, an appraisal, or an assessment must be made, ${ }^{280}$ and the legislature was or should have been aware of both the asymmetry and the necessity. ${ }^{281}$ For instance, the word "carcinogenic" may allow a margin of interpretation (when and at what level can a substance or a product be qualified as such?) and its interpretation may require non-legal expertise as well as the making of predictions. A broad and open-ended word used in a statute such as "reasonable" or "appropriate" can, but should not necessarily be considered as ambiguous or unclear. In the context of the statute in its entirety and on the basis of the applicable methods and canons of construction, the distinction between reasonable and unreasonable may indeed be clear. In such a case, judicial review can be exercised without any particular deference. ${ }^{282}$

In Switzerland, judicial deference to administrative interpretation of statutes especially relates to situations where local circumstances matter, ${ }^{283}$ technical questions are raised, ${ }^{284}$ or the orientation of public policies is at stake. ${ }^{285}$ In Germany, there are three main forms of judicial deference to administrative decisions or other acts, which originate from the administration's discretion (Ermessen der Verwaltung), freedom of planning (planerische Gestaltungsfreiheit), and latitude of judgment (Beurteilungsspielraum). ${ }^{286}$ These three types of deference may overlap and relate to statute interpretation and application. ${ }^{287}$ The first two are instances where the administration has some discretion to choose between consequences once the legal requirements of a statute are met. They are normal features of German administrative

280. Regarding Canada, see DALY, supra note 16, at 73 ("In particular areas, expertise may be indispensable. Risk regulation is a good example. A number of key decisions of the Supreme Court of Canada highlight the relevance of expertise to deciding the appropriate degree of curial deference to accord to a delegated decision-maker." (footnote omitted)). Regarding Germany, see, for example, OSTER, supra note 5, at 191, 313-14; Hoffmann-Riem, supra note 4, at 744-45. Regarding the United States, see, for example, Kavanaugh, supra note 106, at 2153 ("[C]ourts should still defer to agencies in cases involving statutes using broad and open-ended terms like 'reasonable,' 'appropriate,' 'feasible,' or 'practicable."').

281. On this issue, see DALY, supra note 16, at 77-79. Regarding Germany, see Eifert, supra note 9, at 339.

282. On this issue, see Kavanaugh, supra note 106, at 2153-54.

283. See Tribunal fédéral [TF] [Federal Court] June 28, 2000, 126 ARRÊTS DU TRIBUNAL FÉDÉRAL SUISSE (RECUEIL OFFICIEL) [ATF] I 219, 222 (Switz.).

284. See Tribunal fédéral [TF] [Federal Court] Dec. 10, 2010, 137 ARRÊTS DU TRIBUNAL FÉDÉRAL SUISSE (RECUEIL OFFICIEL) [ATF] II 152, 162 (Switz.).

285. See e.g., Tribunal fédéral [TF] [Federal Court] Aug. 31, 2006, 132 ARRÊTS DU TRIBUNAL FÉDÉRAL SUISSE (RECUEIL OFFICIEL) [ATF] II 408, 416-27 (Switz.).

286. See, e.g., OSTER, supra note 5, at 29-68; BosCH, supra note 62, at 5-114.

287. See, e.g., OSTER, supra note 5, at 67 . Regarding Switzerland, see, by analogy, TANQUEREL, supra note 6 , at 220-23. 
law. The last one especially concerns indefinite legal terms used in statutes that the legislature has-explicitly or implicitly ${ }^{288}$-duly authorized the administration to interpret with some latitude (Spielraum). ${ }^{289}$ Reviewing case law and legal literature on this issue, one can note that cases in which judicial deference to administrative statutory interpretation or application is admitted relate mostly to legal norms requiring specific non-legal expertise or the making of predictions, appraisals or assessments; more concretely, the established cases concern professional assessments of public servants, exam situations, complex prognoses, decisions by independent expert panels, and by pluralistically composed panels, such as film classification boards. ${ }^{290}$ The topic is not as controversial in Germany as in the United States, notably because the instances where deference occurs are rather minor. Moreover, most of the cases arise between courts and the hierarchical administration. In other words, judicial deference to administrative statutory interpretation and independent agencies are not connected issues in Germany.

Under the conditions mentioned in this subpart, ${ }^{291}$ judicial deference to administrative statutory interpretation can be seen as acceptable, and even legitimate, in countries where there is room for such deference. Thus, while there may be other specific situations, in some of these countries where such deference could be justified, one may conclude that there is a case for judicial deference, at least when these various conditions are cumulatively met.

288. See Aschke, supra note 30, ๆ 105-06; Schönenbroicher, supra note 242, ๆ 99; Heinrich Amadeus Wolff, $\S 114$, in VERWALTUNGSGERICHTSORDNUNG [ADMINISTRATIVE JUDICIAL CODE] ๆ ๆ 295-96 (Helge Sodan \& Jan Ziekow eds., 5th ed. 2018).

289. See Bundesverfassungsgericht [BVERFG][Federal Constitutional Court] May 31, 2011, 129 ENTSCHEIDUNGEN DES BUNDESVERFASSUNGSGERICHTS [BVERFGE] 1, 2123 (Ger.).

290. See, e.g., Aschke, supra note 30, ๆ 107-26.4; Bosch, supra note 62, at 4850, 63-107, 119-22, 381-88; Hoffmann-Riem, supra note 4, at 744-45; SchmidtAßmann, supra note 60, ๆ 188-217a; Eifert, supra note 9, at 339-41. Regarding exams, see Bundesverfassungsgericht [BVerfG][Federal Constitutional Court] Apr. 17, 1991, 84 ENTSCHEIDUNGEN DES BUNDESVERFASSUNGSGERICHTS [BVERFGE] 34, 52-58 (Ger.).

291. For criteria that are partly close to this approach, see, regarding the United States, Eskridge \& Baer, supra note 78, at 1180 (proposing to consider whether the agency interpretation is "consistent with larger public norms, including constitutional values"; whether it is made "pursuant to a congressional delegation of lawmaking authority"; and whether the agency is "applying special expertise to a technical issue, seriously applying its understanding of the facts to carry out congressional purposes"). The authors conclude that "[w]here an agency has applied its expertise to an issue as to which judges are substantively much less competent, judges should and do take a deferential attitude, subject to rule-of-law limits such as textual plain meanings, legislative compromises, and precedent." Id., at 1202. From a comparative perspective, see Craig, supra note 14, at 402-03. 


\section{Specific Comments Regarding Canada and the United States}

This comparative study suggests that the supreme courts of Canada and the United States have gone quite far in terms of judicial deference to administrative interpretation of statutes. ${ }^{292}$ The study, to a certain extent, supports the doctrines developed in these two countries but also invites reflection regarding their scope.

Firstly, a presumption of deference somehow exists in Canada, ${ }^{293}$ even though its scope is significantly reduced, and the case law is not always straightforward. In the United States, the Chevron doctrine, even with its subsequent limitations, is rather far reaching as it makes a link between statutory ambiguity and "delegation" of some interpretive authority to agencies. ${ }^{294}$ To be fair, the US doctrine of judicial review is quite strict. Moreover, the reviewing court has to defer to the agency's interpretation only if the statutory law is interpreted as delegating interpretive authority to the agency and if the interpretation of an ambiguous statutory provision is within the zone of reasonableness. Courts are then being asked not to invade that zone. From a principled perspective, at least, no other country seems to have ventured so far down the deference path on questions of legal interpretation. Strong legal and contextual reasons may explain and justify some landmark cases in both countries. Nevertheless, does a presumption of deference adequately reflect the role of the courts in an État de droit when it applies to questions of law? Do courts infer too much, institutionally speaking, from the ambiguity of statutes? In short, should a more nuanced approach, for instance along the lines of this Article, ${ }^{295}$ be preferred? Such an approach might actually better protect the Parliament of Canada or the Congress of the United States. ${ }^{296}$

Secondly, procedural safeguards are deemed, in several countries, to require full judicial review of the interpretation of the law and its application to the facts. ${ }^{297}$ In other countries, they do not exclude any judicial deference to administrative interpretation of statutes. Do the doctrines developed in Canada and the United States give sufficient

292. Regarding Canada, see DEAn R. Knight, Vigilance and RESTRAint In the COMMON LAW OF JUDICIAL REviEW 155 (2018) ("Notably, unlike other AngloCommonwealth jurisdictions, ... deference also applies explicitly to questions of lawthat is, resolving matters of interpretation is not regarded as being the sole constitutional preserve of the courts."). Regarding Canada and the United States, see Boughey, supra note 43 , at 37 n. 16 .

293. See supra Parts III.C, VI.B. (1984).

294. See Chevron, U.S.A., Inc. v. Nat. Res. Def. Council, Inc., 467 U.S. 837, 842-43

295. See the test proposed infra Part VII.

296. See supra Part IV.A.4.

297. See supra Parts V.D, VI.A. 
weight to judicial independence and fairness? ${ }^{298}$ This question is delicate and cannot probably be answered in abstracto. Arguably, it should instead be examined on a case-by-case basis or, at least, on a procedure-by-procedure basis. The case law of the European Court of Human Rights is, mutatis mutandis, interesting in this respect. ${ }^{299}$ The test proposed in the conclusion of this Article allows for such an approach.

Thirdly, are all "ambiguous" or "unclear" statutory norms equal under the various doctrines of deference? This question is perhaps provocative, but it aims to invite, here again, a nuanced approach. It is argued, in this Article, that judicial deference should especially relate to those among said norms requiring non-legal expertise for their interpretation, ${ }^{300}$ especially when the making of a prediction, appraisal, or assessment lies at their core. ${ }^{301}$ This approach closely follows the reasoning in the Chevron and Mead decisions of the Supreme Court of the United States ${ }^{\mathbf{3 0 2}}$ and the Vavilov decision of the Supreme Court of Canada, ${ }^{303}$ though it would reduce the breadth of judicial deference to administrative interpretation of statutes. In the test proposed in the conclusion of this Article, the asymmetry of nonlegal expertise is not the starting point of the analysis, but rather a subsequent element for the courts to consider on a nuanced basis.

\section{CONCLUSION}

Judicial deference to administrative statutory interpretation arises in some democracies. Some courts have developed a doctrine in this respect; others have explicitly rejected any idea of deference with regard to the interpretation of the law. It is possible that the first defer

298. For a positive answer, see Daly, supra note 264 , at $145-47$. For a rather negative answer, see Hamburger, supra note 57, at 1251 ("In the end, it must be hoped that the judges themselves will solve the dangers of deference. Although they undoubtedly will continue to enjoy the robes of their office, they need to decide whether they will fill those robes. Under the Constitution, they must exercise an office of independent judgment and must avoid systematic bias in violation of due process, and if they fail to meet these most basic requirements, they will have little right to public respect or even self-respect.").

299. See supra Part V.D.

300. Regarding the United States, see SUnSTEIN \& VERMEULE, supra note 260, at 137-38 (referring, by analogy, to the Kisor decision, according to which "the agency's interpretation must in some way implicate its substantive expertise." 139 S. Ct. 2400, 2417 (2019)).

301. See supra Part VI.C.2.

302. "Steps zero, one and two" of the Chevron/Mead doctrine can be linked to conditions (i), (ii) and (iii) of the test proposed infra Part VII ("step zero" results in particular from condition (iii)).

303. The standard of review imposed on a court and the limits imposed by the rule of law especially result from condition (iii) of the test proposed infra Part VII. 
less than they are supposed to, according to their own doctrine, and that the second actually defer consciously or unconsciously. One of the great merits of a doctrine, such as the ones existing in Canada, Germany, and the United States, is to raise an issue and to open or frame a debate.

Judicial deference to administrative statutory interpretation may be regarded as a pragmatic and realistic way of allocating limited resources and of dealing with the asymmetry of non-legal expertise among administrative bodies and courts, provided that it is framed by several conditions. When these conditions are met, the separation of powers principle is not endangered, and judicial deference in statutory interpretation cases may be described as oil in the complex machinery of checks and balances. ${ }^{304}$ In any event, the legislature retains the final say, ${ }^{305}$ at least ex post and pro futuro.

The legislature may explicitly or actively require or allow judicial deference to administrative statutory interpretation. Courts still have to verify that the legislature has not violated the constitution or international law in countries where the supremacy of the one or the other over statutes is legally enforceable. They have to interpret this authorization in order to determine its scope as well as the intensity of judicial review that may or must be performed.

As statutes rarely deal with the issue of judicial deference to their interpretation, courts themselves must determine whether such deference is permitted or forbidden, generally or in certain cases only. The constitutional, legal, and judicial context prevailing in each country is of great significance in this regard. It may nevertheless provide courts with little, if any, guidance on the specific issue of deference to administrative statutory interpretation and leave them helpless. In this respect, courts may eventually consider adopting a nuanced approach and applying all or part of the following test: When (i) in light of the applicable methods and canons of construction, a statute allows a margin of interpretation, (ii) the administrative interpretation of the statute remains within this margin, and (iii) the applicable international, constitutional, statutory, or other constraints permit or, at least, do not exclude judicial deference either generally or in the case at hand, then courts may or, depending on the country, must defer to the administrative interpretation of the statute, especially when or, depending on the country, provided that (iv) this interpretation requires non-legal expertise, (v) the administrative

304. From a broader-i.e., not focused on statutory interpretation-and comparative perspective, see Zhu, supra note 16, at 15 ("Judicial deference to the administration] is an integral part of the constitutional system, which brings flexibility in the arteriosclerotic separation of powers system, balances the lack of political legitimacy of the courts as well as the lack of expertise when it is at stake.").

305. Regarding the United States, see, for example, Sunstein, supra note 60, at 1634-41; see also Reitz, supra note 4, at 287. 
body enjoys an asymmetry of such expertise as compared to courts, and (vi) the legislature was or should have been aware of both this necessity and this asymmetry. Depending on how condition (iii) is interpreted in a given country, courts could disregard condition (vi). The level of courts' expertise in the relevant subject matter should in principle be determined after taking account of the measures available to judges, including the appointment of experts. The proposed test may notably be followed when the disputed statute interpretation requires the making of a prediction, appraisal or assessment. 